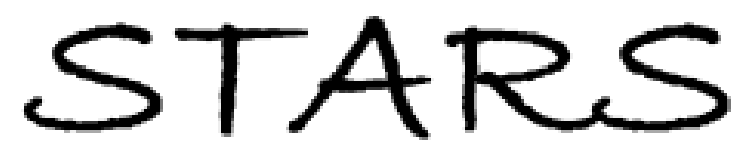

University of Central Florida

STARS

Faculty Scholarship and Creative Works

$9-1-2020$

\title{
Corporate Social Responsibility in International Hotel Chains and its Effects on Local Employees: Scale Development and Empirical Testing in China
}

Chaohui Wang

Runhong $\mathrm{Hu}$

Tingting (Christina) Zhang

University of Central Florida, tingting.zhang@ucf.edu

Part of the Hospitality Administration and Management Commons, and the Tourism and Travel Commons

Find similar works at: https://stars.library.ucf.edu/ucfscholar

University of Central Florida Libraries http://library.ucf.edu

This Paper is brought to you for free and open access by STARS. It has been accepted for inclusion in Faculty Scholarship and Creative Works by an authorized administrator of STARS. For more information, please contact STARS@ucf.edu.

\section{Original Citation}

Wang, C., Hu, R., \& Zhang, T. (Christina). (2020). Corporate social responsibility in international hotel chains and its effects on local employees: Scale development and empirical testing in China. International Journal of Hospitality Management, 90, N.PAG. https://doi.org/10.1016/j.ijhm.2020.102598

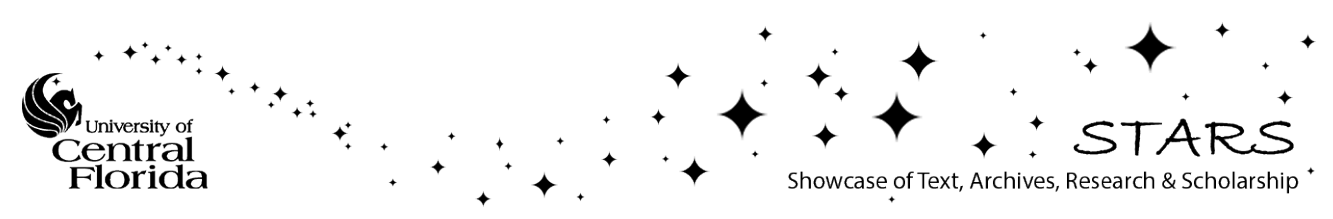


Wang, C., Hu, R., \& Zhang, T. (Christina). (2020). Corporate social responsibility in international hotel chains and its effects on local employees: Scale development and empirical testing in China.InternationalJournalofHospitalityManagement,90, N.PAG.

\title{
Corporate Social Responsibility in International Hotel Chains and Its Effects on Local Employees: Scale Development and Empirical Testing in China
}

\begin{abstract}
This study aims to investigate the corporate social responsibility (CSR) practices of international hotel chains operating in China and their effects on local Chinese employees. As CSR practices vary across countries and contexts, this study developed a scale of CSR metrics, which was based on CSR reports published by international hotel chains in China and a comprehensive literature review. Subsequently, the proposed model, which depicts the relationships between CSR practices and local employee work metrics, was tested with a PLS-SEM. Multiple phases of qualitative and quantitative investigations of 2,451 local Chinese employees of international hotel chains allowed for validating a formative construct of CSR with four dimensions: environment protection, employee wellness, business ethics, and customer wellness. The PLS-SEM results confirmed the significant effects of CSR practices of international hotel chains in China on local Chinese employee engagement, commitment, job satisfaction, and organizational citizenship behaviors. Theoretical and practical implications are presented.
\end{abstract}

Key words: Corporate social responsibility (CSR), Local employees, International hotel chains, Employee engagement, Cultural congruence 


\section{Introduction}

In today's competitive business world, many enterprises have adopted the strategy of corporate social responsibility (CSR) to balance the interests of multiple stakeholders while improving their social reputation and firm image (Kucukusta, Mak, \& Chan, 2013; Lee \& Heo, 2009). For example, Hilton team members volunteered 236,930 hours across 93 countries through 5,000 projects during 2018 Global Week of Service to improve the development of local communities (Hilton, 2019). Ranked $2^{\text {nd }}$ on the World's Best Regarded Companies by Forbes (Hilton, 2019), Hilton has globally supported more than 3,000 apprenticeship programs and trained 20,000 young team members about life-saving skills to strengthen their career and life (Hilton, 2019). For environmental preservation, Hilton used LightStay technology to improve energy use efficacy; as a result, the company has reduced its energy consumption by $22 \%$, carbon emissions by $30 \%$, waste output by $32 \%$, and water usage by $22 \%$ since 2008 (Hilton, 2019). Many other hotels that embrace CSR include Marriott Group (2019), Intercontinental Hotel Group (IHG, 2019), and Shangri-La (2019). Many multinational hotels, such as Hilton, highly invest and engage in CSR activities and receive multiple benefits from this. CSR gives businesses an edge by winning them social credibility and enabling multiple cost reductions (Park \& Levy, 2014).

Hospitality is a service-centric, customer-centered business (Park \& Levy, 2014), which is undeniably a value co-creation process (Lin, Peng, Ren, \& Lin, 2019). In particular, employees are the critical factor in successful value co-creation with customers throughout the course of hospitality service production and delivery. However, many CSR studies have focused on sustainability and industry development (Fatma, Rahman, \& Khan, 2016); macro topics, such as environmental, economic, and social causes (e.g., Fatma et al., 2016); and firm performance (e.g., Lee \& Park, 2009). Little is known about the employee perspective, not to mention cross-cultural issues (i.e. international entities vs. local staff). Thus, the aim of this study was to fill this gap by investigating the effects of international hotel chains' CSR practices on local Chinese employees. 
As scholars have proposed (Tang \& Li, 2009), CSR takes shape with social and cultural elements, which reflects the nature of the organization's relationship with culture. Thus far, most CSR works have been conducted in the context of developed countries (Henderson, 2007), making it immensely important to examine CSR practices in developing countries, such as China, especially in consideration of accelerating globalization (Tang \& Li, 2009). As a developing country, China's business environment differs from that of developed countries, which likely causes multinational companies to practice different CSR activities in China than they do in developed countries. Consequently, the CSR initiatives by multinational firms may not be totally accepted and performed by local Chinese employees. Compared to western culture, Chinese people, from an early age, generally accept the education of Confucianism, which may influence their views about the companies' organizational culture (Anthony Wong \& Hong Gao, 2014). For example, human rights, one of the domains of CSR, has been less debated by people in China than in developed countries (USNews, 2019). Additionally, the cultural concept of guanxi, expression of the classical philosophy of ren (humanity), plays important role in the Chinese business dealings, and also likely affects the implementation and effects of CSR (Gu, Ryan, Bin, \& Wei, 2013). Thus it gains great necessity to figure out whether the CSR practices could be perceived and accepted by local Chinese employees for the multinational companies. This view aligns with the theory of cultural congruence (Huang \& Rundle-Thiele, 2014), which emphasizes the distance between a firm's cultural competence and the cultural needs of its employees.

Although there are some studies related to CSR in international hotel chains, they did not focus its effects on local employees alone, such as CSR/HR managers and employees (e.g., Ko, Chan, \& Wong, 2019). Probably, some scholars explored the CSR in four or five upscale hotels (e.g., Boğan \& Dedeoğlu, 2019; Fu, Li, \& Duan, 2014) or just hospitality companies (e.g., He, Zhang, \& Morrison, 2019), but not emphasizing its development in multinational hotel chains locally. In sum, due to the limited studies on the CSR practices of multinational hotel chains and their effects on 
the work performance of local staff, this study contributes to the literature with its empirical examination of the CSR practices of international hotel chains in China and testing of the CSR effects on local Chinese employees. Based on the analysis of CSR research in the hotel industry, it is indicated that the impacts of CSR on hotel's business performance from the perspective of employee mainly include job satisfaction, work engagement, organizational commitment, and their behavior such as organizational citizenship and employee retention (Serra-Cantallops, Peña-Miranda, Ramón-Cardona, \& Martorell-Cunill, 2018). However, there exists only a few studies having examined the impacts of CSR towards the all of employee performance simultaneously. Therefore, four employee work performance constructs were chosen as dependent variables: employee engagement, employee commitment, organizational citizenship behavior, and employee job satisfaction.

The significance of this study can be assessed from the following points. First, as CSR practices are contextual and have social and cultural backgrounds, to capture the cross-cultural essence of international hotel chains' CSR practices, this study, first, entailed developing and validating a scale for measuring the CSR practices of multinational hotel chains in the context of China using CSR annual reports and prior literature in the CSR domain as its sources. Second, this study, jumping out of the western paradigm, acts as one of the attempts to examine CSR practices in the context of China, thus significantly augmenting the empirical research on this subject in the developing world. Third, this study involved considering cultural congruence and empirically testing the effects of international hotel chains' CSR practices on local employee performance. The findings are valuable for international hotel practitioners who intend to manage their local employees. This study is also important for policymakers because it will allow them to better promote CSR practices among international companies conducting business in local markets.

The structure of the rest of the paper is as follows. First, a comprehensive literature review on CSR from diverse perspectives is provided. Then the four hypotheses and research model based on the literature review are presented. Second, 
the study design and methodology are introduced, followed by the analysis results. Third, the conclusions and implications of the findings are presented. Finally, the limitations and future research directions are discussed.

\section{Literature Review}

\subsection{CSR and its measurement}

The concept of CSR has no universal definition and is associated with many terms, such as corporate social performance, corporate sustainability, corporate social responsiveness, corporate citizenship, corporate accountability, responsible business, corporate social entrepreneurship, and corporate social and environmental responsibility (Aguinis \& Glavas, 2012; Carroll \& Shabana, 2010; Park \& Levy, 2014). Dahlsrud (2008) identified 37 different definitions of CSR by 27 researchers during 1980-2003. However, as Carroll and Shabana (2010) stated, many more research works have defined CSR using diverse methodologies. Some organizations, such as the European Commission (2001, p. 6), have defined CSR as a "concept whereby companies integrate social and environmental concerns in their business operations and in their interactions with their stakeholders on a voluntary basis", which is the most cited definition on websites by Dahlsrud (2008)'s findings. Therefore, this definition is adopted in the current study. As noted in Table 1, most definitions were developed from the classic pyramid (Carroll, 1999), from economic and legal to ethical and philanthropic perspectives. Several other works have defined CSR from the perspectives of a sustainable development framework (Fatma et al., 2016), stakeholder theory (Öberseder, Schlegelmilch, Murphy, \& Gruber, 2013), and Elkington's triple bottom line (Tsai, Tsang, \& Cheng, 2012). Analyzing CSR practices in four- or five-star rated hotels in Hong Kong, China, Kucukusta et al. (2013) proposed five dimensions depicting CSR - namely, vision and values, community, marketplace, workforce, and environment. It is worth noting that only a few studies, such as that of Öberseder et al. (2013), have conceptualized CSR on the basis of the industrial practices of various corporations in recent years, though CSR is unanimously regarded as an industrial practice matter by its nature (Fatma \& Rahman, 
2014). Therefore, there appeared to be an urgent need to review past CSR practices and combine the existing conceptual propositions in the research to comprehensively examine the conceptualization of CSR and, thus, prepare a scale for measuring the CSR construct.

\section{Please insert Table 1 here}

As Martínez et al. (2013) put it, we should attach great importance to the development of valid and reliable measures of CSR. However, as Turker (2009) suggested, it is difficult to measure corporate social performance. A review of the academic literature revealed the existence of various methodologies for measuring CSR. Those that have been found feasible for this include reputation indices (e.g., Fatma et al., 2016), databases (e.g., Maignan \& Ferrell, 2000), content analysis (e.g., Levy \& Park, 2011), expert assessments (e.g., Maignan \& Ferrell, 2000), and surveys of organizational managers (e.g., Bohdanowicz \& Zientara, 2008).

As mentioned above, most studies involving CSR measures entailed developing a CSR scale on the basis of the theory of sustainable development (e.g., Fatma et al., 2016) and stakeholder theory (e.g., Glavas \& Kelley, 2014). Little is known from the employee perspective because previous studies mainly focused on the consumer, such as Martínez et al. (2013). Furthermore, Turker's (2009) CSR scale was based on Wheeler and Sillanpaa's (1997) typology for selecting relative stakeholder groups and corresponding responsibilities for these stakeholders provided in previous literature. By means of the conceptual framework of sustainable development, Fatma et al. (2016) conducted an intensive review of literature and developed a scale reflecting three dimensions of hotel CSR perceived by consumers. Glavas and Kelley (2014) built their scale of employee perceptions of CSR in the food and agriculture industry by integrating stakeholder theory and ethics. Therefore, the existing research gap could be filled by a comprehensive metric of the CSR practices of international hotel chains from the perspective of employees.

In hospitality services, CSR has been frequently discussed as one of the top goals 
of many hotels. For several decades, hotels have been focusing increasingly on the environmental and social impacts of their development and operations (Goldstein \& Primlani, 2012). Levy and Park (2011) noted a total of 129 CSR practices that have been undertaken in the hotel sector. As displayed in Table 2, hotels' CSR practices are mainly carried out in environmental, economic, and social aspects. IHG (2019), for example, operates an IHG Green Engage system to make the hotel environmentally friendly, organizes a charitable fundraising week and IHG Academy programs to support the local community, and ensures responsible procurement to guarantee product quality.

\section{Please insert Table 2 here}

As discussed above, no study prior to this one has focused on the CSR of international hotels in China and undertaken comprehensive scale development to assess effects of CSR on local Chinese employees, which highlights the uniqueness of the current study. The underlying reason is as follows: When international hotels operate in host countries, the issue of cultural congruence should be taken into account. It is meaningful to explore how the implementation of CSR by international hotels can be accepted by local Chinese employees.

\subsection{CSR in international hotels and local employees}

As globalization accelerates, multinational corporations spread across every corner of the globe (Tang \& Li, 2009). However, as Kelemen and Papasolomou (2007) underlined, there seems to be a cultural distance between senior management and foreign employees in the tourism and hospitality industry. Hence, how can multinational corporations adapt their CSR strategies and initiatives to ensure that employees understand them, thereby realizing cultural congruence? Cultural congruence refers to the distance between the cultural competence offered by the organization to employees and the employees' cultural needs (Costantino, Malgady, \& Primavera, 2009). When employee-organization values coincide, this means that they are in congruence or fit (Chatman, 1989), which can relieve cultural conflicts and 
increase levels of employee satisfaction, organizational commitment, and retention (Hoffman \& Woehr, 2006; Huang \& Rundle-Thiele, 2014; Verquer, Beehr, \& Wagner, 2003). When congruence is not achieved, negative outcomes ensue, such as turnover (Schneider, Goldstein, \& Smith, 1995).

To achieve cultural congruence, international hotel chains take relevant actions to engage employees when promoting their CSR strategy in a different cultural context. They do this, firstly, by reaching out to local employees via involvement in the local community, such as creating jobs, offering programs and skills training for local youth and disabilities, and undertaking community service activities and hope projects for children living in poverty (Hilton, 2019; IHG, 2019; Marriott, 2019; Shangri-La, 2019). Moreover, they seek local employees' feedback on the hotel's contribution to the local community, relying on surveys, meetings, e-voice, and other forms of communication (IHG, 2019). In addition to the aforementioned actions, international hotels frequently organize learning and training programs on the theme of CSR as an important corporate culture and strategy (IHG, 2019; Marriott, 2019).

According to Kim, Rhou, Uysal, and Kwon (2017), employees' perceptions of CSR practices in the hotel industry positively influence their attitudes toward their work organization and their job performance. When employees perceive that their organization is involved in socially responsible activities, they are more likely to develop a positive attitude toward, and be highly engaged in, the organization as well as their job (Ilkhanizadeh \& Karatepe, 2017). According to Ilkhanizadeh and Karatepe (2017), high levels of CSR result in higher employee engagement, which is defined as "a positive, fulfilling, work related state of mind that is characterized by vigour, dedication, and absorption" (Schaufeli, Bakker, \& Salanova, 2006, p. 704). Glavas and Kelley (2014) found that CSR perceived by employees has a positive impact on job satisfaction, defined as a positive emotional state reflecting affective responses to the work environment (Kalleberg, 1977). In addition, Youn, Lee, and Lee (2018) validated that job satisfaction mediates the positive effect of perceived CSR on organizational commitment, which refers to an individual's psychological 
attachment to, and identification with, the organization (Mowday, Porter, \& Steers, 2013). Moreover, it has been found that organizational citizenship behavior, which Organ (1988) defined as individual employee behavior that is discretionary, is positively influenced by perceived CSR (Lin, Lyau, Tsai, Chen, \& Chiu, 2010). Furthermore, Aguinis and Glavas (2012) concluded that working for a socially responsible company leads to increased organizational identification, employee engagement, organizational citizenship behavior, employee commitment, in-role performance, and improved employee relations.

This study investigates the relationship between local employees' perceptions of CSR and employee attitudes and behaviors within a model that applies social identity theory and deontic justice theory. Within social identity theory, individuals tend to classify themselves and others into different social categories, and perceived membership with social organizations influences individuals's self-concept (Peterson, 2004; Tajfel \& Turner, 1986). In the context of business organizations, positive external reputations, which may be exerted by socially responsible behavior, are likely to enhance employees' social identity with positive organizational values and affective connections to the organization (Lee, Song, Lee, Lee, \& Bernhard, 2013; Peterson, 2004). As supported by deontic justice theory, individuals often feel principled moral obligations to maintain justice rules and react against unfair treatment and behavior, not only for oneself but also for others (Folger, 2001). CSR acts as important organizational justice strategy aims at its stakeholders (Boğan \& Dedeoğlu, 2019; Rupp, Ganapathi, Aguilera, \& Williams, 2006). It is widely evidenced that when employees perceived fair behavior of an organization, they tend to develop positive attitudes towards their job and exhibit organizational citizenship behavior (Cropanzano, Massaro, \& Becker, 2017). Based on the above interpretation, in the present study, the authors posited that CSR perceptions in international hotel chains would positively affect local employees' attitudes and behaviors, such as engagement, job satisfaction, commitment, and organizational citizenship behavior. The research model is represented in Figure 1. 
H1. CSR implemented by international hotel chains will positively influence local employees' engagement.

H2. CSR implemented by international hotel chains will positively influence local employees' job satisfaction.

H3. CSR implemented by international hotel chains will positively influence local employees' commitment.

H4. CSR implemented by international hotel chains will positively influence local employees' organizational citizenship behavior.

\section{Please insert Figure 1 here.}

\subsection{CSR in China}

According to the Material and Quantitative Indicators Database (2018), there has been a significant increase in the number of CSR reports released by Chinese companies since 2009, with this figure reaching 2,033 in 2014. However, since 2014, the number of CSR reports issued has been declining year by year, falling to 1,106 in 2018. The quantitative change in CSR reports is tightly associated with the relevant laws and regulations issued by the government. This is also applicable to the hospitality industry. In accordance with the Green Hotel standard, many hotels use recyclable materials and waste management to take on their environmental responsibility (Peng, Wei, \& Li, 2013). In the process of collecting CSR reports of the top 50 hotel groups, it was found that it is easier to access related reports and news of foreign hotels than of Chinese hotels. Most Chinese hotels do not have a dedicated CSR section on their official website to present their CSR strategy and relevant projects. Additionally, some Chinese hotels disclose CSR information with just a few pages in annual reports $(\mathrm{Li}, 2018)$. It is not difficult to observe that CSR receives scant attention in China compared to developed countries.

However, it is noteworthy that in China, investment in CSR practices, to a certain degree, can relieve regulatory pressure from the government (McGehee, 
Wattanakamolchai, Perdue, \& Calvert, 2009) by improving community relations and the local quality of life (e.g., Kirk, 1998) and, eventually, gaining policy support from the government. From the perspective of Chinese employee in the field of tourism and hospitality industry, firms that practice CSR-to-stakeholder positively affect their loyalty and commitment, which is may due to the unique Chinese culture with the characteristics of collectivism and Confucianism (Anthony \& Hong, 2014). Moreover, it is also proved by Anthony and Hong (2014) that CSR-to-employee and CSR-to-customer contribute to the nutrition of corporate culture including four dimensions of employee development, customer orientation, harmony and innovation (Tsui, Wang, \& Xin, 2006). The effects of CSR on Chinese employees are also explored by $\mathrm{Fu}, \mathrm{Li}, \&$ Duan (2014). They found that perceptions of social responsibility reputation would motivate upscale hotel's full-time employees to have emotional attachment to their firm and conduct organizational citizenship behavior (Fu et al., 2014).

Overall, it is notable that firms may reap enormous benefits when their stakeholders perceive them as carrying out socially responsible activities (Fu, Ye, \& Law, 2014). Thus, CSR in China deserves research attention. As globalization accelerates and many international hotel chains enter the Chinese market, it is necessary for foreign hotels to gain the support from its local staff, customers, and gain favorable policies from the local authorities to stay sustainably competitive.

\section{Methodology and Results}

\subsection{Study design}

As the extant literature provides no commonly used scale for measuring the CSR practices of international hotel chains in China (see Section 2.1), both the literature and practices in the CSR domain were taken into consideration to develop the scale for assessing CSR practices of international hotel chains in China. The scale development process was based on the study of Churchill (1979). The detailed scale development process is described in section 3.2. After generating and validating a scale of CSR practices of international hotel chains in China in two phases 
(exploratory and confirmatory) of data collection and analysis, the proposed hypotheses were tested. In total, the data collected represent 2,451 Chinese hotel employees working for international hotel chains in China.

\subsection{Methodological steps}

Figure 2 depicts an overview of the methodological steps in the current study. First, this study followed the suggestions of Churchill (1979) to develop and validate a multi-item measure of CSR in international hotel chains operating in China (see Step I, Step II, Step III). Then, we adopted PLS-SEM approach to test the proposed model underlying the relationships between CSR in international hotel chains and local Chinese employee metrics (see Step IV).

Please insert Figure 2 here

\section{Step I. Initial item generation}

Based on a comprehensive literature review (see section 2.1-2.3), specific domains of the CSR construct were identified. The newest CSR reports by top 50 international hotel groups operating in China, 18 in total, were textually analyzed by two researchers (one data analysis specialist and one author in the research team) simultaneously using MAXQDA version 12 package. A codebook was initially designed according to the literature review and saturation was obtained in the content analysis process (Kunneman et al., 2017). Categorizations and themes were identified after obtaining $90 \%$ similarity between the two content analysis results, achieving the cutoff threshold of $80 \%$ inter-rater agreement (Müller-Frommeyer, Aymans, Bargmann, Kauffeld, \& Herrmann, 2017). Consequently, 18 measurement items in total (see Table 3) were generated with six themes representing the CSR dimensions-namely, environmentally sustainable strategy, community support, human rights, employee wellness, business ethics, and customer wellness.

Please insert Table 3 here

Step II. Item refinement 
Ten scholars in the hospitality and tourism sustainability field independently assessed these 18 items. These scholars gave the following suggestions: (i) more concise expression of some items; (ii) overlapped categorization; and (iii) incomplete and some ignored aspects. Revisions of the measurement items were made on the basis of these experts' suggestions. For example, three items — "wage security: wages are paid on time and reasonable overtime pay is paid" "fair competition and cooperation: fair competition among industries, no competition at low prices, advocating win-win cooperation" and "right to know: corporate quality assurance, price changes, corporate social responsibility reports, etc."-were proposed for inclusion in the categories of employee wellness, business ethics, and customer wellness, respectively. Additionally, 20 hotel managers were invited to evaluate the wording of each item to ensure clear phrasing and expressions. Per the hotel managers' advice, the category of environmentally sustainable strategy was revised as "environmental protection." Consequently, 21 items were generated to measure the CSR practices of international hotel chains in China.

To further refine the measurement items, a quantitative approach was adopted. Data were collected from local employees of international hotel chains in China, including five different international hotel brands. All questionnaire items, from CSR reports mainly in English version, were initially prepared in English and then translated into Chinese using the back-translation method (Karatepe \& Choubtarash, 2014). The questionnaire was divided into three parts: (i) screening questions to exclude participants who were not currently working for an international hotel chain in China as well as general work-related questions including work experience and awareness of CSR practices, which is in the form of asking employee whether this item is performed in their hotel; (ii) main questions including 21 measurement items for CSR practices; and (iii) demographic information questions including gender, age, income, education, ethnics, marital status, etc. To increase the quality of responses, two attention check questions were added to the questionnaire (i.e. "Please select number two for this question to demonstrate your attention" and "Please select number four for this question to demonstrate attention"). Further, to ensure that the 
respondents understood the key concepts of CSR, the purpose of the study and a short introduction to CSR practices and significance were provided in a cover letter attached to the questionnaire. The responses were gathered through two means: (i) electronic questionnaire hosted on the platform of WenJuanXing, which is a popular online survey platform in China, and (ii) paper questionnaire distributed and collected in the hotels. Data collection took place from November 2018 to January 2019 in eastern areas of China, and 1,293 responses were obtained. The data collection yielded 605 usable responses after initial data screening (i.e., incomplete answers, invariance of responses, failure to pass the attention checks).

The respondents' demographic information is presented in Table 4. Among the respondents, the proportion of female employees was $15 \%$ more than male employees (42.5\%). All respondents were under 60 years old, mostly between 18 and 35 years old (63.3\%). Most respondents had gone to college (36.9\%) or university (21.3\%). Only $1.2 \%$ of respondents had a master's degree or higher. Most respondents had an income under 8,000 RMB (92.9\%) per month. Regarding the respondents' work backgrounds, most had work experience of one-to-three years $(27.4 \%)$ or less than one year $(32.2 \%)$. About $40 \%$ of respondents had worked in the hotel industry for more than three years. Most were primary-level employees (62.8\%), followed by primary-level managers (24.5\%), middle-level managers (10.7\%), and high-level managers $(2.0 \%)$. In terms of department, most respondents worked in the food and beverage (41.8\%) and housekeeping (21.3\%) departments.

\section{Please insert Table 4 here}

Then, to cope with the missing value, the algorithm of expectation maximization (EM) was performed (Ali, 2016). The analysis results revealed that missing value are at random and do not affect the following data analysis (Little' s MCAR test: chi-square $=8479.573, \mathrm{df}=6020$, significance $=0.000$ ). In addition, descriptive statistics of measurement items and normality test results were displayed in Appendix 1. It is indicated from the descriptive statistics that there is no outlier and all items distributed in a reasonable range. As for normality, the two measures of skewness and 
kurtosis $(<1)$ could be examined to determine the normality of dataset (Hair, 2014). As shown in Appendix 1, the empirical data do not totally meet the requirement of normality. Therefore, this study adopted PLS-SEM, which is a nonparametric statistical method and does not require the data to be normally distributed, to conduct model testing (Rigdon, 2016).

To solve the biasing effect caused by self-report survey, Harman's single factor was conducted to address common method bias. As demonstrated by statistical results, each factor accounted for less than $50 \%$ of the covariation in the dataset, which suggests that common method bias is not a big issue in this study (Podsakoff, MacKenzie, Lee, \& Podsakoff, 2003).

The appropriateness of the 21 items was determined via exploratory factor analysis (EFA), which is aimed at identifying and confirming the connections between latent and observed variables. An EFA was performed on the 605 cases by means of SPSS 22.0. According to the EFA output (see Table 5), no cross-loading in excess of 0.5 was observed, but items CSR 4, CSR 5, CSR 6, CSR 7, CSR 8, CSR 9, CSR 10, and CSR 11 were eliminated due to low factor loadings $(<0.5$ as suggested by Hair, Black, Babin, \& Anderson, 2010). In addition to the principal component analysis, another factor analysis was performed on the remaining construct items using maximum likelihood estimation with oblique rotation because the resultant factors were expected to be correlated (Chen, Mak, \& Li, 2013). Using eigenvalues of > 1.0 as guidelines for factor extraction (Hair et al., 2010), a multidimensional factor occurred with 13 items explaining $60.41 \%$ of the total variance. This gave way to four dimensions based on non-fixed factor extraction standards: environment protection, employee wellness, business ethics, and customer wellness. The Cronbach's alpha scores for the four dimensions of the construct were 0.796, 0.799, 0.834 , and 0.868 , respectively, which exceeded the recommended threshold of 0.70 (Nunnally \& Bernstein, 1994), Therefore, construct reliability was confirmed.

Please insert Table 5 here

\section{Step III. Measurement validity assessment}


Next, to assess measurement validity, another round of data collection occurred among local employees in international hotels mainly concentrated in eastern China. The questionnaire was revised on the basis of the EFA results. With the support of hotel management, the questionnaire was distributed among Chinese employees working for international hotels, and the data collection process took about four weeks from June to July 2019. A total of 1,158 completed questionnaires were collected, and after being subjected to a screening analysis, 1,023 usable responses were used for the following data analysis. The sample description is displayed in Table 6. Fifty-seven percent of respondents were female and $42.3 \%$ were male. They were mostly below 60 years old (95.5\%). Most of them had completed high school or below (46.9\%), followed by a two-year college degree (41.3\%). Most had an income of less than 8,000 RMB (97\%) per month. Most had been in their current job for one-to-three years $(38.7 \%)$, with the rest being in theirs for less than one year $(21.7 \%)$, more than five years $(20.4 \%)$, and between three and five years $(19.2 \%)$. Regarding the number of years working in the hotel industry, most had done so for one-to-three years $(31.1 \%)$, followed by 5-10 years $(23.0 \%)$, three-to-five years $(20.4 \%)$, less than one year $(12.9 \%)$, and over 10 years $(12.6 \%)$. Concerning job level, there were more primary-level employees (56.1\%) and primary-level managers (33.6\%), compared to middle-level managers (9.5\%) and high-level managers (0.8\%). As for department, the majority of respondents worked in the food and beverage (33.7\%) and housekeeping (32.4\%) departments.

\section{Please insert Table 6 here.}

The measurement model was evaluated from the two aspects of convergence validity and discriminant validity. First, convergence validity was assessed via factor loadings, composite reliability (CR), and average variance extracted (AVE) (Hair, Hult, Ringle, \& Sarstedt, 2017). As shown in Table 7, the loadings of all items exceeded the recommended value of 0.5 (Hair et al., 2017). The construct CR values, which illustrate the degree to which the construct indicators indicate the latent construct, met the minimum requirement of 0.7 (Hair et al., 2013). AVE, which is a 
value revealing the overall amount of variance in the indicators accounted for by the latent construct, exceeded the threshold value of 0.5 (Hair et al., 2013).

\section{Please insert Table 7 here}

Second, the measurement model was examined for discriminant validity. As Table 8 shows, discriminant validity was supported because the square root of the AVE (shown on the diagonal) of each construct was greater than the related inter-construct correlations in the construct correlation matrix.

\section{Please insert Table 8 here}

Lastly, the weights of first-order constructs on the designated second-order construct are displayed in Table 9. The displayed results indicate that CSR is a second-order factor with four dimensions-namely, environment protection, employee wellness, business ethics, and customer wellness. The weights and t-values of all dimensions denote first-order constructs with CSR as the designated second-order construct. In addition, the parameter of variance inflation factor (VIF) was assessed to identify the issues of multi-collinearity before evaluating the structural models. Following the suggestions of Hair, Sarstedt, Ringle, \& Mena (2012), the VIF scores for each first-order construct are below the cut-off criterion of 5, which indicates that collinearity is not a serious issue concern.

\section{Please insert Table 9 here}

\section{Step IV. Model testing}

The structural model and hypotheses were tested by applying a partial least squares structural equation modeling (PLS-SEM) using SmartPLS software. As stated in Step II, the approach of PLS is more appropriate for this study, because it offers fewer restrictions on data normality (Hair et al., 2017). Additionally, PLS-SEM can be used to deal with complex models with both reflective and formative measures (Usakli \& Kucukergin, 2018; Richter, Sinkovics, Ringle, \& Schlägel, 2016), and is particularly useful for predictive and explorative purposes with its focus on the explained variance of the endogenous constructs (Ali, Rasoolimanesh, Sarstedt, 
Ringle, \& Ryu, 2018; Nitzl, Roldan, \& Cepeda, 2016). In view of the purpose of this study and the little research about the relationship between CSR perceptions of local Chinese employees of international hotel chains and employees' attitudes and behaviors, PLS-SEM was identified as well-established technique for testing path model hypothesis, compared to Covariance Based-SEM approach. Due to its advantages, PLS-SEM has been increasingly applied in the field of hospitality and tourism (Ali et al., 2018; Usakli \& Kucukergin, 2018).

To evaluate the proposed relationships between CSR and employee performance (i.e., employee engagement, employee commitment, organizational citizenship behavior, and job satisfaction), during the second round of data collection, questions regarding the four employee performance metrics were added to the questionnaire. Specifically, a seven-item scale was adapted from Llorens, Schaufeli, Bakker, and Salanova (2007) to measure employee engagement. A six-item scale was derived from Farh, Earley, and Lin (1997) to measure organizational citizenship behavior. Employee commitment was measured with four items taken from $\mathrm{He}$, $\mathrm{Li}$, and Keung Lai (2011). Four items on employee job satisfaction were adopted from Cheng and O-Yang (2018). All items were measured on a seven-point Likert scale ranging from "Strongly Disagree" (1) to "Strongly Agree" (7). As the scale for CSR had been validated in the aforementioned steps, a bootstrapping procedure (Chin, Peterson, \& Brown, 2008) with 2,000 iterations was performed on the dataset to examine the statistical significance of the path coefficients between the four dimensions of CSR (i.e., environmental protection, employee wellness, business ethics, and customer wellness) and the four employee metrics. Since PLS does not generate overall goodness-of-fit indices, $\mathrm{R}^{2}$ can be applied to evaluate the explanatory power of the predictor variables on each construct. According to Chin et al. (2008), endogenous latent variables can be classified into three types: substantial $\left(\mathrm{R}^{2}=0.67\right)$, moderate $\left(\mathrm{R}^{2}=0.33\right)$, or weak $\left(\mathrm{R}^{2}=0.19\right)$. Thus, our results indicated that employee engagement $\left(R^{2}=0.20\right)$, employee job satisfaction $\left(R^{2}=0.167\right)$, employee commitment $\left(\mathrm{R}^{2}=0.161\right)$, and organizational citizenship behavior $\left(\mathrm{R}^{2}=0.237\right)$ could be understood as moderate, weak, weak, and moderate, respectively (see Figure 3). 
Except for job satisfaction and employee commitment, which had the weakest degrees of prediction, the other two employee metrics predicted the construct of CSR moderately in order of organizational citizenship behavior and employee engagement. Following the suggestions of Hair, Risher, Sarstedt, \& Ringle (2019), the effect size $\left(\mathrm{f}^{2}\right)$ was assessed to account for how exogenous construct affects a particular endogenous latent variable in terms of $\mathrm{R}^{2}$. As a guideline, the thresholds of $\mathrm{f}^{2}$ of 0.02 , 0.15, 0.35 can be depicted as weak, moderate, and strong effects (Cohen, 1988). Accordingly, as shown in Table 10, CSR perception have moderate effects on employee engagement $\left(f^{2}=0.34\right)$, employee commitment $\left(f^{2}=0.33\right)$, employee job satisfaction $\left(\mathrm{f}^{2}=0.25\right)$, and organizational citizenship behavior $\left(\mathrm{f}^{2}=0.24\right)$. In addition, the value of $\mathrm{Q}^{2}$ estimated through the blindfolding procedure was assessed to serve as a criterion for predictive relevance of the research model proposed (Sarstedt, Ringle, Smith, Reams, \& Hair, 2014). As suggested by Hair et al. (2019), Q ${ }^{2}$ for employee engagement $\left(Q^{2}=0.14\right)$, employee commitment $\left(Q^{2}=0.15\right)$, employee job satisfaction $\left(Q^{2}=0.06\right)$ and organizational citizenship behavior $\left(Q^{2}=0.09\right)$, larger than zero, indicated acceptable predictive accuracy of the structural model.

\section{Please insert Figure 3 here}

The complete results of the structural model and hypothesis testing are presented in Table 10. As these results indicate, the implementation of CSR in international hotel chains has significant effects on the attitudes and behaviors of local employees, such as their engagement $(\beta=0.446, p<0.001)$, job satisfaction $(\beta=0.408, p<0.001)$, commitment $(\beta=0.401, p<0.001)$, and organizational citizenship behavior $(\beta=0.487$, $\mathrm{p}<0.001)$, providing support for all proposed hypotheses $(\mathrm{H} 1-\mathrm{H} 4)$. As the findings indicate, when local Chinese employees perceive that their international corporation is involved in socially responsible activities in China, they are more likely to be satisfied with their job, committed to the organization, and actively engaged in their work. Moreover, they are willing to exhibit helping behavior to cooperate with their colleagues and make suggestions for the development of organization. Therefore, it is critical for international hotel chains in China to implement CSR initiatives that are 
easily perceived by local Chinese employees, such as environment protection, employee wellness, business ethics, and customer wellness, to satisfy and engage their employees and enhance their commitment and organizational citizenship behavior.

\section{Please insert Table 10 here}

\section{Discussion and Implications}

Aimed at addressing the gap in CSR research, the focus of this study was on investigating CSR practices in international hotel chains in China and examining their effects on local employees on the basis of the theory of cultural congruence. First, through the process of content analysis of the latest CSR reports of international hotels, review of relevant literature and refinement, CSR was validated as a second-order complex construct with four dimensions including environment protection, employee wellness, business ethics, and customer wellness. The environment protection dimension includes three items: energy saving, resource saving, and waste management. There are four items comprising the employee wellness dimension-namely, wage security, health and safety promotion, mutual communication and engagement, and training and development. The business ethics dimension consists of anti-corruption and bribery, responsible procurement and sourcing, and fair competition and cooperation. Three items pertain to the customer wellness dimension - that is, safety and privacy, health and well-being, and right to know. Moreover, this study adopted a PLS-SEM approach to validate the significant effects of CSR practices perceived by local Chinese employees on employee engagement, commitment, job satisfaction, and organizational citizenship behaviors. The findings of this study illuminate numerous important theoretical and practical implications, which are discussed in the following section.

\subsection{Theoretical implications}

This study innovatively entailed developing and validating a scale measuring CSR practices of international hotel chains in the context of China. CSR is formed and developed in specific social and cultural contexts and has unique contextual 
characteristics. As Blowfield and Frynas (2010) proposed, there are some issues in the developing world regarding CSR performance that require different solutions from those in developed economies. The findings of previous studies regarding measurement scales, which predominantly concern developed countries, cannot be generalized and applied to Chinese social and cultural settings. Hence, it is meaningful to focus on the cross-cultural essence of CSR practices by multinational hotel chains.

This study contributes to the scarce literature owing to its examination of CSR practices within the context of China. A general review of extant studies and CSR practices revealed that much of the research has focused on western contexts (Whelan, 2007). Although some scholars have recognized the bias and attempted to examine CSR in different social and cultural contexts, such as China (e.g., Gu \& Ryan, 2011), Japan (e.g., Ilkhanizadeh \& Karatepe, 2017), Pakistan (e.g., Ali, Rehman, Ali, Yousaf, \& Zia, 2010), South Korea (e.g., Kim et al., 2017), India (e.g., Fatma et al., 2016), and Thailand (e.g., Supanti \& Butcher, 2018), the majority of these studies were based on the western paradigm (Tang \& Li, 2009), which mainly focuses on macro issues, such as environment, economic, and society, from the perspective of firm performance. This study represents one of attempts to investigate China, which is the typical representative of developing economies, to explore how CSR is performed and perceived by local employees. Special attention was paid to understanding the distance between the cultural competence of international hotel chains and the cultural needs of their local employees.

Hence, the theory of cultural congruence was taken into consideration to conduct an empirical test on the effects of international hotel chains' CSR practices on local Chinese employees. Given the realistic background of globalization, a growing number of scholars in the field of CSR are conducting cross-culture research and probing into the connection between local social, cultural, and economic contexts and corporate globalization (Stohl, Stohl, \& Townsley, 2007). For example, Tang and Li (2009) explored how leading Chinese and global companies established in China 
communicate their CSR practices to Chinese stakeholders and whether the country of origin affects CSR communication. Different from their research, this study enriched the literature by measuring Chinese employees' perceptions of CSR practices of international hotel chains to evaluate the effects of those CSR practices on the local Chinese employees' work performance.

Moreover, research on the effects on local employees exerted by international hotel chains in the field of CSR remains scarce. A related study is that of Maignan and Ferrell (2000), who examined corporate citizenship behaviors in a cross-cultural setting: US and France. They demonstrated that international hotel chains meet cultural challenges with local employees when they enter a new country to conduct business. Organizations must strategize to make the local employees accept and implement the organizational values (Maignan \& Ferrell, 2000). The current study provides international organizations with an accessible approach for engaging with their local employees when they start business in a new country or culturally different region. Drawing on the social identity theory and deontic justice theory, the study findings indicate that international hotel chains' CSR practices, including employee wellness, customer wellness, environment protection, and business ethics, positively influence the local employees' engagement, commitment, organizational citizenship behaviors, and job satisfaction. This study, therefore, contributes to the existing literature on CSR and cross-cultural human resource management.

\subsection{Practical implications}

When international hotels enter into a new market in different cultural settings, cultural congruence should be on the agenda to balance the employer's offerings and employees' needs (Huang \& Rundle-Thiele, 2014). Enabling local employees to evaluate the CSR initiatives of international hotel chains with respect to each dimension of CSR is a major contribution. Based on the study findings, the CSR practices of international hotel chains in China can be evaluated by the following four dimensions: environmental protection, employee wellness, business ethics, and customer wellness. Accordingly, international hotel managers specifically need to 
guarantee employee wellness by ensuring wage security, health and safety promotion, mutual communication and engagement in the corporation's development, and regular training and development opportunities. In addition, the customer is regarded as an important factor that greatly affects the work attitudes and behaviors of employees ( $\mathrm{Li}$ \& Hsu, 2016). Therefore, customer wellness, ranging from safety and privacy, health and well-being, and right to know, should not be ignored by management when operating CSR practices in China. As the Chinese government is paying increasing attention to the environment, for example, by banning plastic (Yuan, 2019) and undertaking garbage classification (Jiang et al., 2019), this is also raising local Chinese employees' awareness of environment protection. They are increasingly realizing the importance of environmentally sustainable development in their business and lives and are showing a great willingness to participate in related activities and exhibit pro-environment behaviors, such as participating in Earth Hour, which advocates turning off the lights for an hour between 8:30 p.m. and 9:30 p.m. on the last Saturday in March (Net, 2019). Hence, international hotels operating in China must take some environmental measures, such as energy saving, resource saving, and waste management, which is emphasized in one of the CSR dimensions in our findings. Last but not least, business ethics, including anti-corruption and bribery, responsible procurement and sourcing, fair competition, and cooperation, should not be ignored by multinational hotel chains operating in China. Business ethics are tightly linked to the reputation enhancement of a business (Lee, Choi, Moon, \& Babin, 2014), and the perception of employees in this regard positively influences the development of person-organization fit and lowers their turnover intention (Jung, Namkung, \& Yoon, 2010).

The results relating to the main effect of perceived CSR of international hotels suggest that employees feel more positive about their hotel in accordance with the theory of social identity (Liu, Thomas, \& Higgs, 2019) and, thus, tend to have greater job satisfaction, commitment to their organization, and engagement in their work when they positively perceive their company's engagement in socially responsible 
activities. Moreover, they are more willing to exhibit organizational citizenship behavior, such as self-enhancement in their work quality, assisting colleagues with their assignments, voicing their views, and making constructive recommendations for new proposals or changes (Farh et al., 1997; Raub, 2008). These findings provide some managerial implications for international hotels in China that intend to manage local employees. For example, managers and executives may, first, take effective measures to communicate their efforts toward socially responsible practices to employees to improve the employees' perception of CSR. International hotel chains in China may consider the following measures: releasing CSR reports annually and related news reports regularly, conducting training courses frequently regarding the topic of CSR by inviting experts in this field, and administering CSR perception surveys, similar to the well-known job satisfaction surveys, to ensure that local employees profoundly perceive the CSR practices in their organization. In addition, managers might consider investing in CSR initiatives, since such investments would significantly enhance employees' job satisfaction and commitment to the company, which echoes the findings of Youn et al. (2018).

In view of the cultural difference, international hotels need to adjust to the local circumstances and take corresponding actions to facilitate the local employees' perception of CSR practices, consequently achieving culture congruence. For instance, as increasing attention is paid to the issues of garbage classification (Jiang et al., 2019) and poverty alleviation (News, 2018) in China, international hotels could launch, for example, a garbage classification and recycling program from the environmental perspective and hope projects and disaster relief from the societal perspective. Furthermore, when local employees perceive that their hotel practices CSR, they are more likely to perform their jobs, raise their voices, and exhibit helping behavior to both the organization and their colleagues, which effectively enhances their job performance and lowers turnover intention (Kim et al., 2017). This further validates the significance of performing CSR for international hotel chains operating in China. More effective and targeted efforts relating to CSR could be undertaken from the 
perspective of local employees. Additionally, it should not be ignored that suggestions and feedback from local employees in China will greatly promote the practice of CSR and achieve cultural congruence.

\section{Limitations and Future Research Directions}

First, the sampled hotels are mainly located in eastern areas of China. Therefore, the results may not reflect employees' perceptions of CSR in other regions of China. This necessitates confirmation of the extent to which the findings can be generalized to other regions in China in theory and will allow for obtaining greater insight into international hotel chains operating in China in practice. Second, the focus of our study was limited to employee job satisfaction, commitment, engagement, and organizational citizenship behavior as the four most important outcomes. Future empirical studies may take into account additional critical variables, such as job crafting, job embeddedness, or turnover intention, to further evaluate the impact of CSR on work performance. Third, in recognition of the cross-cultural essence of CSR practices of international hotel chains in China, cultural elements play a vital role in the process of how CSR strategies are perceived by local employees. Based on the proposed conceptual model, some cultural factors could be taken into account, such as cultural values, cultural distance, or cross-cultural competence, to further capture the cultural elements involved in gauging the relationship between CSR and employee behaviors. 


\section{References}

Aguilera, R. V., Rupp, D. E., Williams, C. A., \& Ganapathi, J. (2007). Putting the S back in corporate social responsibility: A multi-level theory of social change in organizations. Academy of Management Review, 32, 836-86.

Aguinis, H., 2011. Organizational responsibility: doing good and doing well. In:Zedeck, S. (Ed.), APA Handbook of Industrial and Organizational Psychology, vol. 3. American Psychological Association, Washington, DC, pp. 855-879.

Aguinis, H., \& Glavas, A. (2012). What We Know and Don’t Know About Corporate Social Responsibility. Journal of Management, 38(4), 932-968.

Ali, F. (2016). Hotel website quality, perceived flow, customer satisfaction and purchase intention. Journal of Hospitality and Tourism Technology, 7(2), 213-228.

Ali, F., Rasoolimanesh, S., Sarstedt, M., Ringle, C., \& Ryu, K. (2018). An assessment of the use of partial least squares structural equation modeling (PLS-SEM) in hospitality research. International Journal of Contemporary Hospitality Management, 30(1), 514-538.

Ali, I., Rehman, K. U., Ali, S. I., Yousaf, J., \& Zia, M. (2010). Corporate social responsibility influences, employee commitment and organizational performance. African Journal of Business Management, 4(12), 2796-2801.

Anthony Wong, I., \& Hong Gao, J. (2014). Exploring the direct and indirect effects of CSR on organizational commitment. International Journal of Contemporary Hospitality Management, 26(4), 500 - 525.

Bhattacharya, C. B., \& Sen, S. (2004). Doing better at doing good: When, why, and how consumers respond to corporate social initiatives. California Management Review, 47, 9-24.

Blowfield, M., \& Frynas, J. G. (2010). Setting new agendas: critical perspectives on 
corporate social responsibility in the developing world. International Affairs, 81(3), 499-513.

Boğan, E., \& Dedeoğlu, B. B. (2019). The effects of hotel employees' CSR perceptions on trust in organization: Moderating role of employees , self-experienced CSR perceptions. Journal of Hospitality and Tourism Insights, 2(4), 391-408.

Bohdanowicz, P., \& Zientara, P. (2008). Corporate social responsibility in hospitality: Issues and implications. A case study of scandic. Scandinavian Journal of Hospitality and Tourism, 8(4), 271-293.

Brands that do good also do well. (2003). HSMAI Marketing Review, 20(3), 40.

Carroll, A. B. (1979). A Three-Dimensional Conceptual Model of Corporate Performance. The Academy of Management Review, 4(4), 497.

Carroll, A. B. (1991). The pyramid of corporate social responsibility: Toward the moral management of organizational stakeholders. Business Horizons, 34(4), $39-48$.

Carroll, A. B. (1998). The Four Faces of Corporate Citizenship. Business and Society Review, 100-101(1), 1-7.

Carroll, A. B. (1999). Corporate social responsibility evolution of a definitional construct. Business \& Society, 38(3), 268-295.

Carroll, A. B., \& Shabana, K. M. (2010). The business case for corporate social responsibility: a review of concepts, research and practice. International Journal of Management Reviews, 12(1), 85-105.

Chen, Y., Mak, B., \& Li, Z. (2013). Quality deterioration in package tours: The interplay of asymmetric information and reputation. Tourism Management, 38, 43-54.

Chatman, J. A. (1989). Improving Interactional Organizational Research: A Model of 
Person-Organization Fit. Academy of Management Review, 14(3), 333-349.

Cheng, J.-C., \& O-Yang, Y. (2018). Hotel employee job crafting, burnout, and satisfaction: The moderating role of perceived organizational support. International Journal of Hospitality Management, 72, 78-85.

Chin, W. W., Peterson, R. A., \& Brown, P. S. (2008). Structural equation modelling in marketing: some practical reminders. Journal of Marketing Theory and Practice, 16(4), 287-298.

Christensen, L. J., Peirce, E., Hartman, L. P., Hoffman, W. M., \& Carrier, J. (2007). Ethics, CSR, and sustainability education in the Financial Times top 50 global business schools: Baseline data and future research directions. Journal of Business Ethics, 73(4), 347-368.

Churchill, G. A. (1979). A Paradigm for Developing Better Measures of Marketing Constructs. Journal of Marketing Research, 16(1), 64.

Cohen, J. (1988), Statistical Power Analysis for the Behavioral Sciences, 2nd ed., Lawrence Erlbaum Associates,USA.

Costantino, G., Malgady, R. G., \& Primavera, L. H. (2009). Congruence between culturally competent treatment and cultural needs of older Latinos. Journal of Consulting and Clinical Psychology, 77(5), 941-949.

Cropanzano, R. S., Massaro, S., \& Becker, W. J. (2016). Deontic Justice and Organizational Neuroscience. Journal of Business Ethics, 144(4), 733-754.

Dahlsrud, A. (2008). How corporate social responsibility is defined: an analysis of 37 definitions. Corporate Social Responsibility and Environmental Management, 15(1), 1-13.

Du, S., \& Vieira, E. T., Jr. (2012). Striving for legitimacy through corporate social responsibility: insights from oil companies. Journal of Business Ethics, 110(4), 413-427. 
Elkington, J., 1998. Cannibals with Forks: the Triple Bottom Line of 21st Century Business. Capstone Publishing, Oxford.

European Commission. (2001). Green paper: Promoting a European framework for corporate social responsibility. Brussels, Belgium: Commission of the European Communities.

Farh, J.-L., Earley, P. C., \& Lin, S.-C. (1997). Impetus for Action: A Cultural Analysis of Justice and Organizational Citizenship Behavior in Chinese Society.

Administrative Science Quarterly, 42(3), 421.

Fatma, M., \& Rahman, Z. (2014). Building a corporate identity using corporate social responsibility: a website based study of Indian banks. Social Responsibility Journal, 10(4), 591-601.

Fatma, M., Rahman, Z., \& Khan, I. (2016). Measuring consumer perception of CSR in tourism industry: Scale development and validation. Journal of Hospitality and Tourism Management, 27, 39-48.

Folger, R. (2001). Fairness as deonance. In S. W. Gilliland, D. D. Steiner, \& D. P. Skarlicki (Eds.), Research in social issues in management (pp. 3-31). Greenwich, CT: Information Age.

Fu, H., Li, Y., \& Duan, Y. (2014). Does employee-perceived reputation contribute to citizenship behavior? The mediating role of organizational commitment. International Journal of Contemporary Hospitality Management, 26(4), 593-609.

Fu, H., Ye, B. H., \& Law, R. (2014). You do well and I do well? The behavioral consequences of corporate social responsibility. International Journal of Hospitality Management, 40, 62-70.

Glavas, A., \& Kelley, K. (2014). The Effects of Perceived Corporate Social Responsibility on Employee Attitudes. Business Ethics Quarterly, 24(02), 165-202. 
Goldstein, K. A., \& Primlani, R. V. (2012). Current trends and opportunities in hotel sustainability. HVS Sustainability Services, 31.

Gu, H., \& Ryan, C. (2011). Ethics and corporate social responsibility - An analysis of the views of Chinese hotel managers. International Journal of Hospitality Management, 30(4), 875-885.

Gu, H., Ryan, C., Bin, L., \& Wei, G. (2013). Political connections, guanxi and adoption of CSR policies in the Chinese hotel industry: Is there a link? Tourism Management, 34, 231-235.

Hair, J. F. (2014). A primer on partial least squares structural equations modeling (PLS-SEM). Thousand Oaks: SAGE Publications.

Hair, J. F., Black, W., Babin, B. J., \& Anderson, R. (2010). Multivariate data analysis (7th ed.). NJ: Prentice Hall/Pearson.

Hair, J.F., Hult, G.T.M., Ringle, C., \& Sarstedt, M. (2013), A Primer on Partial Least Squares Structural Equation Modelling (PLS-SEM), Sage Publications, London.

Hair, J. F., Hult, G. T. M., Ringle, C., \& Sarstedt, M. (2017). A primer on partial least squares structural equation modeling (PLS-SEM) (2nd ed.). Thousand Oaks, CA: Sage Publications.

Hair, J. F., Risher, J. J., Sarstedt, M., \& Ringle, C. M. (2019). When to use and how to report the results of PLS-SEM. European Business Review, 31(1), 2-24.

Hair, J. F., Sarstedt, M., Ringle, C. M., \& Mena, J. A. (2012). An assessment of the use of partial least squares structural equation modeling in marketing research. Journal of the Academy of Marketing Science, 40(3), 414-433.

He, J., Zhang, H., \& Morrison, A. M. (2019). The impacts of corporate social responsibility on organization citizenship behavior and task performance in hospitality: A sequential mediation model. International Journal of Contemporary Hospitality Management. doi.org/10.1108/IJCHM-05-2018-0378 
Henderson, J. C. (2007). Corporate social responsibility and tourism: hotel companies in Phuket, Thailand, after the Indian Ocean tsunami. International Journal of Hospitality Management, 26(1), 228-239.

He, Y., Li, W., \& Keung Lai, K. (2011). Service climate, employee commitment and customer satisfaction. International Journal of Contemporary Hospitality Management, 23(5), 592-607.

Hilton.com, 2019. 2018 Corporate Responsibility Report. Retrieved on 01 August 2019 from https://cr.hilton.com/social-impact/

Hoffman, B. J., \& Woehr, D. J. (2006). A quantitative review of the relationship between person-organization fit and behavioral outcomes. Journal of Vocational Behavior, 68(3), 389-399.

Huang, Y.-T., \& Rundle-Thiele, S. (2014). The moderating effect of cultural congruence on the internal marketing practice and employee satisfaction relationship: An empirical examination of Australian and Taiwanese born tourism employees. Tourism Management, 42, 196-206.

IHG.com, 2019. 2017 Responsible Business Executive Summary. Retrieved on 01 August 2019 from https://www.ihgplc.com/responsible-business

Ilkhanizadeh, S., \& Karatepe, O. M. (2017). An examination of the consequences of corporate social responsibility in the airline industry: Work engagement, career satisfaction, and voice behavior. Journal of Air Transport Management, 59, 8-17.

Jiang. W., He., X. R., Du. K., Wang. Y. L., Guan, G. F., \& An. L. M. (2019). Garbage classification: the beautiful refraction of "new fashion". Retrieved 21 August 2019 from http://www.gov.cn/xinwen/2019-08/20/content_5422720.htm.

Jung, H. S., Namkung, Y., \& Yoon, H. H. (2010). The effects of employees' business ethical value on person-organization fit and turnover intent in the foodservice industry. International Journal of Hospitality Management, 29(3), 0-546. 
Kalleberg, A. L. (1977). Work Values and Job Rewards: A Theory of Job Satisfaction. American Sociological Review, 42(1), 124.

Karatepe, O. M., \& Choubtarash, H. (2014). The effects of perceived crowding, emotional dissonance, and emotional exhaustion on critical job outcomes: A study of ground staff in the airline industry. Journal of Air Transport Management, 40, 182-191.

Kelemen, M., \& Papasolomou, I. (2007). Internal marketing: a qualitative study of culture change in the UK banking sector. Journal of Marketing Management, 23(7-8), 745-767.

Kim, H. L., Rhou, Y., Uysal, M., \& Kwon, N. (2017). An examination of the links between corporate social responsibility (CSR) and its internal consequences. International Journal of Hospitality Management, 61, 26-34.

Kim, J. (Sunny), Song, H. J., \& Lee, C.-K. (2016). Effects of corporate social responsibility and internal marketing on organizational commitment and turnover intentions. International Journal of Hospitality Management, 55, 25-32.

Kirk, D. (1998). Attitudes to environmental management held by a group of hotel managers in Edinburgh. International Journal of Hospitality Management, 17(1), $33-47$.

Kitzmueller, M., \& Shimshack, J. (2012). Economic perspectives on corporate social responsibility. Journal of Economic Literature, 50(1), 51-84.

Ko, A., Chan, A., \& Wong, S. C. (2019). A scale development study of CSR: hotel employees' perceptions. International Journal of Contemporary Hospitality Management, 31(4), 1857-1884.

Kunneman, M., Pel-Littel, R., Bouwman, F. H., Gillissen, F., Schoonenboom, N. S. M., Claus, J. J., Flier, W. M. V. D., \& Smets, E. M. A. (2017). Patients' and caregivers' views on conversations and shared decision making in diagnostic 
testing for Alzheimer's disease: The ABIDE project. Alzheimer's \& Dementia: Translational Research \& Clinical Interventions, 3(3), 314-322.

Kucukusta, D., Mak, A., \& Chan, X. (2013). Corporate social responsibility practices in four and five-star hotels: Perspectives from Hong Kong visitors. International Journal of Hospitality Management, 34, 19-30.

Lee, C.-K., Song, H.-J., Lee, H.-M., Lee, S., \& Bernhard, B. J. (2013). The impact of CSR on casino employees' organizational trust, job satisfaction, and customer orientation: An empirical examination of responsible gambling strategies. International Journal of Hospitality Management, 33, 406-415.

Lee, S., \& Heo, C. Y. (2009). Corporate social responsibility and customer satisfaction among US publicly traded hotels and restaurants. International Journal of Hospitality Management, 28(4), 635-637.

Lee, S., \& Park, S.-Y. (2009). Do socially responsible activities help hotels and casinos achieve their financial goals? International Journal of Hospitality Management, 28(1), 105-112.

Lee, S., Singal, M., \& Kang, K. H. (2013). The corporate social responsibility-financial performance link in the U.S. restaurant industry: Do economic conditions matter? International Journal of Hospitality Management, 32, 2-10.

Lee, Y.-K., Choi, J., Moon, B., \& Babin, B. J. (2014). Codes of ethics, corporate philanthropy, and employee responses. International Journal of Hospitality Management, 39, 97-106.

Levy, S. E., \& Park, S.-Y. (2011). An Analysis of CSR Activities in the Lodging Industry. Journal of Hospitality and Tourism Management, 18(1), 147-154.

Li, H. (2018). Research on Current Situation of Corporate Social Responsibility Information Disclosure. Lanzhou Journal, 10, 162-173. 
Li, M., \& Hsu, C. H. C. (2016). Linking customer-employee exchange and employee innovative behavior. International Journal of Hospitality Management, 56, 87-97.

Lin, C.-P., Lyau, N.-M., Tsai, Y.-H., Chen, W.-Y., \& Chiu, C.-K. (2010). Modeling Corporate Citizenship and Its Relationship with Organizational Citizenship Behaviors. Journal of Business Ethics, 95(3), 357-372.

Lin, P. M. C., Peng, K.-L., Ren, L., \& Lin, C.-W. (2019). Hospitality co-creation with mobility-impaired people. International Journal of Hospitality Management. In Press.

Liu, J., Thomas, J. M., \& Higgs, S. (2019). The relationship between social identity, descriptive social norms and eating intentions and behaviors. Journal of Experimental Social Psychology, 82, 217-230.

Llorens, S., Schaufeli, W., Bakker, A., \& Salanova, M. (2007). Does a positive gain spiral of resources, efficacy beliefs and engagement exist? Computers in Human Behavior, 23(1), 825-841.

Maignan, I., \& Ferrell, O. C. (2000). Measuring corporate citizenship in two countries: The case of the United States and France. Journal of Business Ethics, 23(3), 283-297.

Marriott.com, 2019. 2017 Marriott Sustainability and Social Impact Report. Retrieved on 01 August 2019 from https://serve360.marriott.com/

Martínez, P., Pérez, A., \& Rodríguez del Bosque, I. (2013). Measuring Corporate Social Responsibility in tourism: Development and validation of an efficient measurement scale in the hospitality industry. Journal of Travel \& Tourism Marketing, 30(4), 365-385.

Material and Quantitative Indicators Database, 2018. CSR report. Retrieved on 05 January 2019 from http://www.sustainabilityreport.cn/CSRReport_Stats.asp 
McGehee, N. G., Wattanakamolchai, S., Perdue, R. R., \& Calvert, E. O. (2009). Corporate social responsibility within the U.S. lodging industry: An exploratory study. Journal of Hospitality \& Tourism Research, 33(3), 417-437.

McGuire, J. B., Sundgren, A., \& Schneeweis, T. (1988). Corporate social responsibility and firm financial performance. Academy of Management Journal, 31(4), 854-872.

McWilliams, A., \& Siegel, D. S. (2001). Corporate social responsibility: A theory of the firm perspective. Academy of Management Review, 26, 117-127.

Mowday, R. T., Porter, L. W. \& Steers, R. M. (2013), Employee-Organisation Linkages: The Psychology of Commitment, Absenteeism, and Turnover, Academic Press, New York.

Müller-Frommeyer, L. C., Aymans, S. C., Bargmann, C., Kauffeld, S., \& Herrmann, C. (2017). Introducing Competency Models as a Tool for Holistic Competency Development in Learning Factories: Challenges, Example and Future Application. Procedia Manufacturing, 9, 307-314.

Net. R. M. (2019). Earth Hour Intercontinental Resort Sanya Tianfang 60 Activities to help the environment. Retrived 21 August 2019 from http://www.sohu.com/a/304966854_114731.

News. C. Y. O. (2018). Hope projects boost the rid of the poverty. Retrived 21 August 2019 from http://news.cyol.com/content/2018-03/26/content 17052246.htm.

Nitzl, C., Roldan, J. L., \& Cepeda, G. (2016). Mediation analysis in partial least squares path modeling. Industrial Management \& Data Systems, 116(9), 1849-1864.

Nunnally, J. C., \& Bernstein, I. H. (1994). The assessment of reliability. Psychometric theory, 3, 248-292.

Organ, D.W. (1988), Organizational Citizenship Behavior: The Good Soldier 
Syndrome, Lexington, MA: Lexington Books.

Öberseder, M., Schlegelmilch, B. B., Murphy, P. E., \& Gruber, V. (2013). Consumers' Perceptions of Corporate Social Responsibility: Scale Development and Validation. Journal of Business Ethics, 124(1), 101-115.

Podsakoff, P. M., MacKenzie, S. B., Lee, J.-Y., \& Podsakoff, N. P. (2003). Common method biases in behavioral research: A critical review of the literature and recommended remedies. Journal of Applied Psychology, 88(5), 879-903.

Panwar, R., Rinne, T., Hansen, E., \& Juslin, H. (2006). Corporate responsibility: Balancing economic, environmental, and social issues in the forest products industry. Forest Products Journal, 56(2), 4-12.

Park, S.-Y., \& E. Levy, S. (2014). Corporate social responsibility: perspectives of hotel frontline employees. International Journal of Contemporary Hospitality Management, 26(3), 332-348.

Peng, X., Wei, J., \& Li, Y. (2013). CSR practices of China's hotel companies: content analysis of CSR information of top 15 hotel groups. Tourism Tribune, 28(3), $52-61$.

Peterson, D.K. (2004). The relationship between perceptions of corporate citizenship and organizational commitment. Business Society, 43(3), 296-319.

Raub, S. (2008). Does bureaucracy kill individual initiative? The impact of structure on organizational citizenship behavior in the hospitality industry. International Journal of Hospitality Management, 27(2), 179-186.

Rhou, Y., Singal, M., \& Koh, Y. (2016). CSR and financial performance: The role of CSR awareness in the restaurant industry. International Journal of Hospitality Management, 57, 30-39.

Rigdon, E. E. (2016). Choosing PLS path modeling as analytical method in european management research: A realist perspective. European Management Journal, 
34(6), 598-605.

Richter, N. F., Sinkovics, R. R., Ringle, C. M., \& Schlägel, C. (2016). A critical look at the use of SEM in international business research. International Marketing Review, 33(3), 376-404.

Ruf, B. M., Muralidhar, K., \& Paul, K. (1998). The development of a systematic, aggregate measure of corporate social performance. Journal of Management, 24(1), 119-133.

Rupp, D.E., Ganapathi, J., Aguilera, R.V., \& Williams, C.A. (2006). Employee reactions to corporate social responsibility: an organizational justice framework. Journal of Organizational Behavior, 27(4), 537-543.

Sarstedt, M., Ringle, C.M., Smith, D., Reams, R. \& Hair, J.F. (2014). Partial least squares structural equation modeling (PLS-SEM): a useful tool for family business researchers. Journal of Family Business Strategy, 5(1), 105-115.

Schaufeli, W. B., Bakker, A. B., \& Salanova, M. (2006). The Measurement of Work Engagement With a Short Questionnaire. Educational and Psychological Measurement, 66(4), 701-716.

Schneider, B., Goldstein, H.M., Smith, D.B. (1995). The ASA framework: an update. Personnel Psychology, 48, 747-773.

Serra-Cantallops, A., Peña-Miranda, D. D., Ramón-Cardona, J., \& Martorell-Cunill, O. (2018). Progress in Research on CSR and the Hotel Industry (2006-2015). Cornell Hospitality Quarterly, 59(1), 15-38.

Shangri-La.com, 2019. Shangri-La Hotels and Resorts 2015 UN Global Compact Communication on Progress. Retrieved on 01 August 2019 from http://www.shangri-la.com/cn/corporate/about-us/corporate-social-responsibility/su stainability/

Shaw, S., \& Thomas, C. (2006). Discussion Note: Social and Cultural Dimensions of 
Air Travel Demand: Hyper-Mobility in the UK? Journal of Sustainable Tourism, 14(2), 209-215.

Stanaland, A. J., Lwin, M. O., \& Murphy, P. E. (2011). Consumer perceptions of the antecedents and consequences of corporate social responsibility. Journal of Business Ethics, 102(1), 47-55.

Stohl, M., Stohl, C., \& Townsley, N. (2007). A new generation of global corporate social responsibility. In S. May, G. Cheney, \& J. Roper (Eds.), The debate over corporate social responsibility (pp. 30-44). New York: Oxford University Press.

Su, L., Pan, Y., \& Chen, X. (2017). Corporate social responsibility: Findings from the Chinese hospitality industry. Journal of Retailing and Consumer Services, 34, 240-247.

Supanti, D., \& Butcher, K. (2018). Is corporate social responsibility (CSR) participation the pathway to foster meaningful work and helping behavior for millennials? International Journal of Hospitality Management, In Press.

Tajfel, H., \& Turner, J. C. (1986). The social identity theory of intergroup behavior. In S. Worchel, \& W. G. Austin (Eds.). Psychology of intergroup relations (pp. 7 24). (2 $2^{\text {nd }}$ ed.). Chicago, IL: Nelson-Hall.

Tang, L., \& Li, H. (2009). Corporate social responsibility communication of Chinese and global corporations in China. Public Relations Review, 35(3), 199-212.

Theodoulidis, B., Diaz, D., Crotto, F., \& Rancati, E. (2017). Exploring corporate social responsibility and financial performance through stakeholder theory in the tourism industries. Tourism Management, 62, 173-188.

Tian, Z., Wang, R., \& Yang, W. (2011). Consumer responses to corporate social responsibility (CSR) in China. Journal of Business Ethics, 101, 197-212.

Tsai, H., Tsang, N. K. F., \& Cheng, S. K. Y. (2012). Hotel employees' perceptions on corporate social responsibility: The case of Hong Kong. International Journal of 
Hospitality Management, 31(4), 1143-1154.

Tsui, A.S., Wang, H. \& Xin, K.R. (2006). Organizational culture in China: an analysis of culture dimensions and culture types. Management \& Organization Review, 2(3), 345-376.

Turker, D. (2009). Measuring Corporate Social Responsibility: A Scale Development Study. Journal of Business Ethics, 85(4), 411-427.

Usakli, A., \& Kucukergin, K. (2018). Using partial least squares structural equation modeling in hospitality and tourism: Do researchers follow practical guidelines? International Journal of Contemporary Hospitality Management, 30(11), 3462-3512.

USNews, 2019. Countries Seen to Care About Human Rights. Retrieved on 04 April 2019 from https://www.usnews.com/news/best-countries/articles/the-10-countries-that-carethe-most-about-human-rights-according-to-perception

Verquer, M. L., Beehr, T. A., \& Wagner, S. H. (2003). A meta-analysis of relations between person-organization fit and work attitudes. Journal of Vocational Behavior, 63(3), 473-489.

Waddock, S. A., \& Graves, S. B. (1997). The corporate social performance-financial performance link. Strategic Management Journal, 18(4), 303-319.

Wheeler, D., \& M. Sillanpaa (1997). The Stakeholder Corporation: A Blueprint for Maximazing Stakeholder Value (Pitman, London).

Whelan, G. (2007). Corporate social responsibility in Asia: A confucian context. In S. May, G. Cheney, \& J. Roper (Eds.), The debate over corporate social responsibility (pp. 105-118). New York: Oxford University Press.

World Business Council for Sustainable Development. (1999). Corporate social responsibility: Meeting changing expectations. Geneva: Author. 
Youn, H., Lee, K., \& Lee, S. (2018). Effects of corporate social responsibility on employees in the casino industry. Tourism Management, 68, 328-335.

Yuan. G. K. (2019). From the "Plastic Limit Order" to the "Plastic Bug Ban" is the upgrade of ecological civilization. Retrived 21 August 2019 from http://guancha.gmw.cn/2019-02/27/content_32572577.htm. 


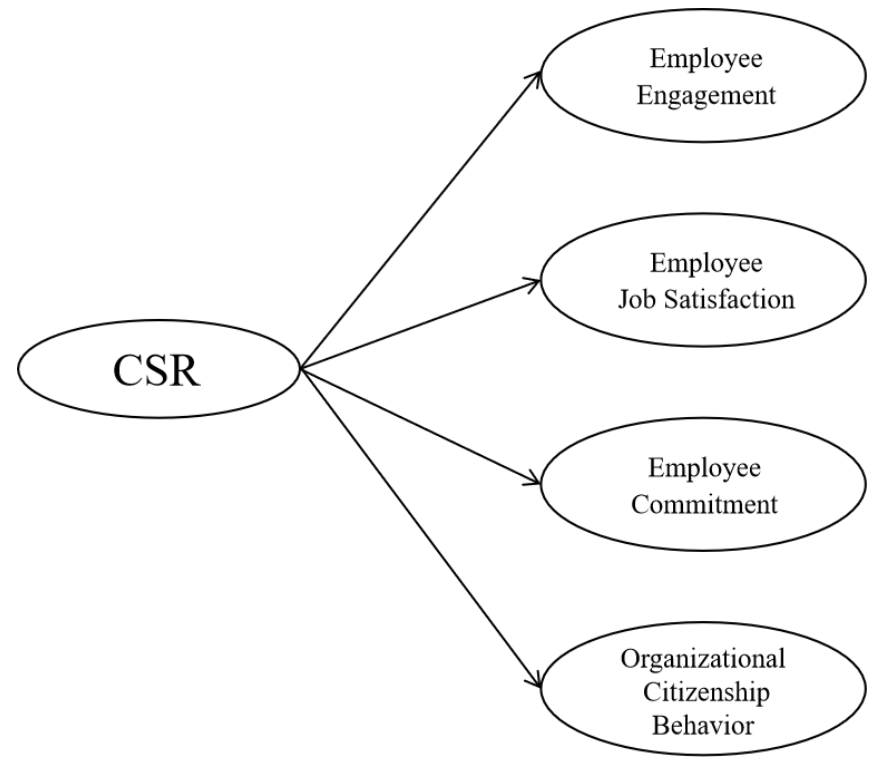

Figure. 1. Proposed research model. 


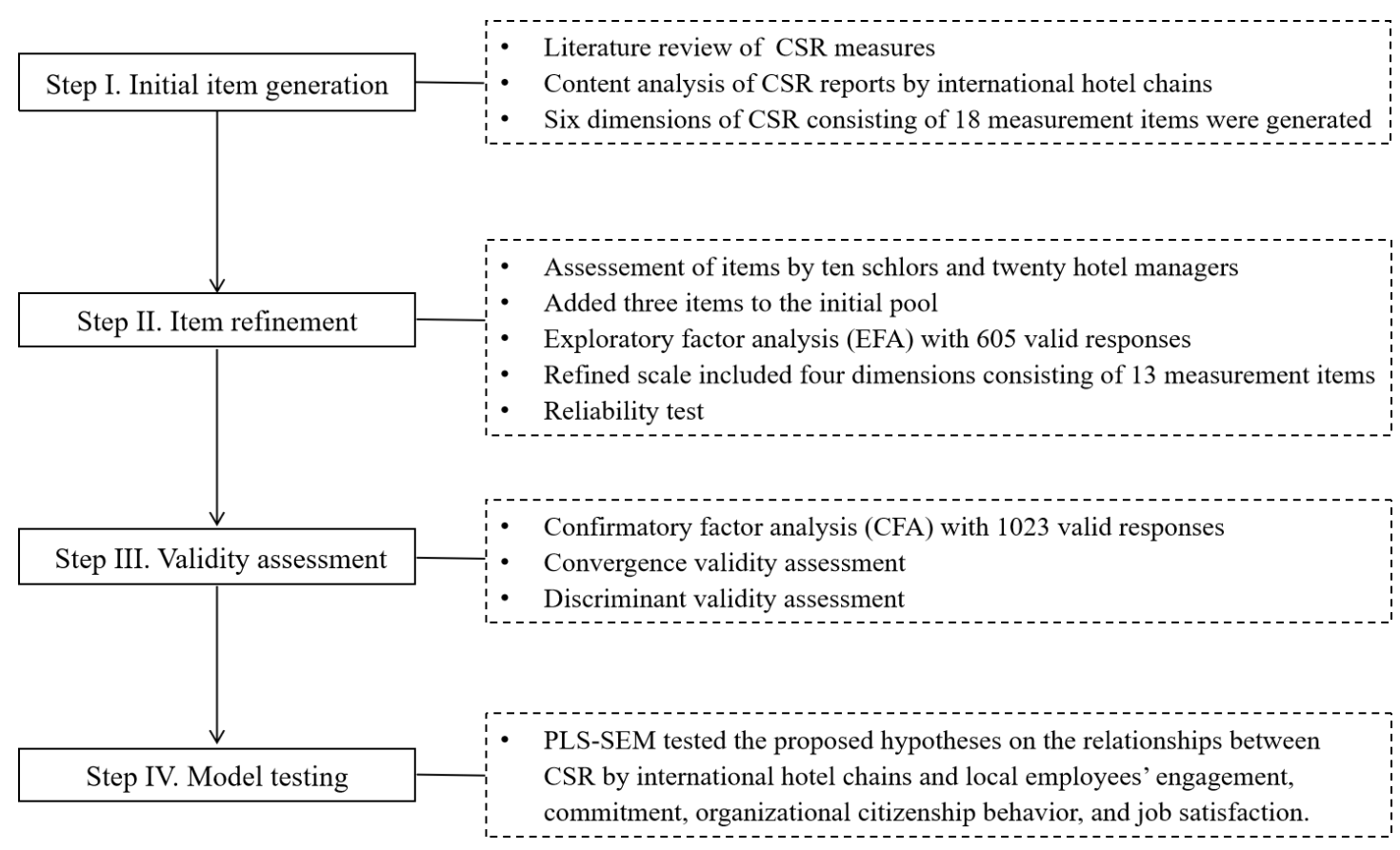

Figure. 2. Methodological steps 


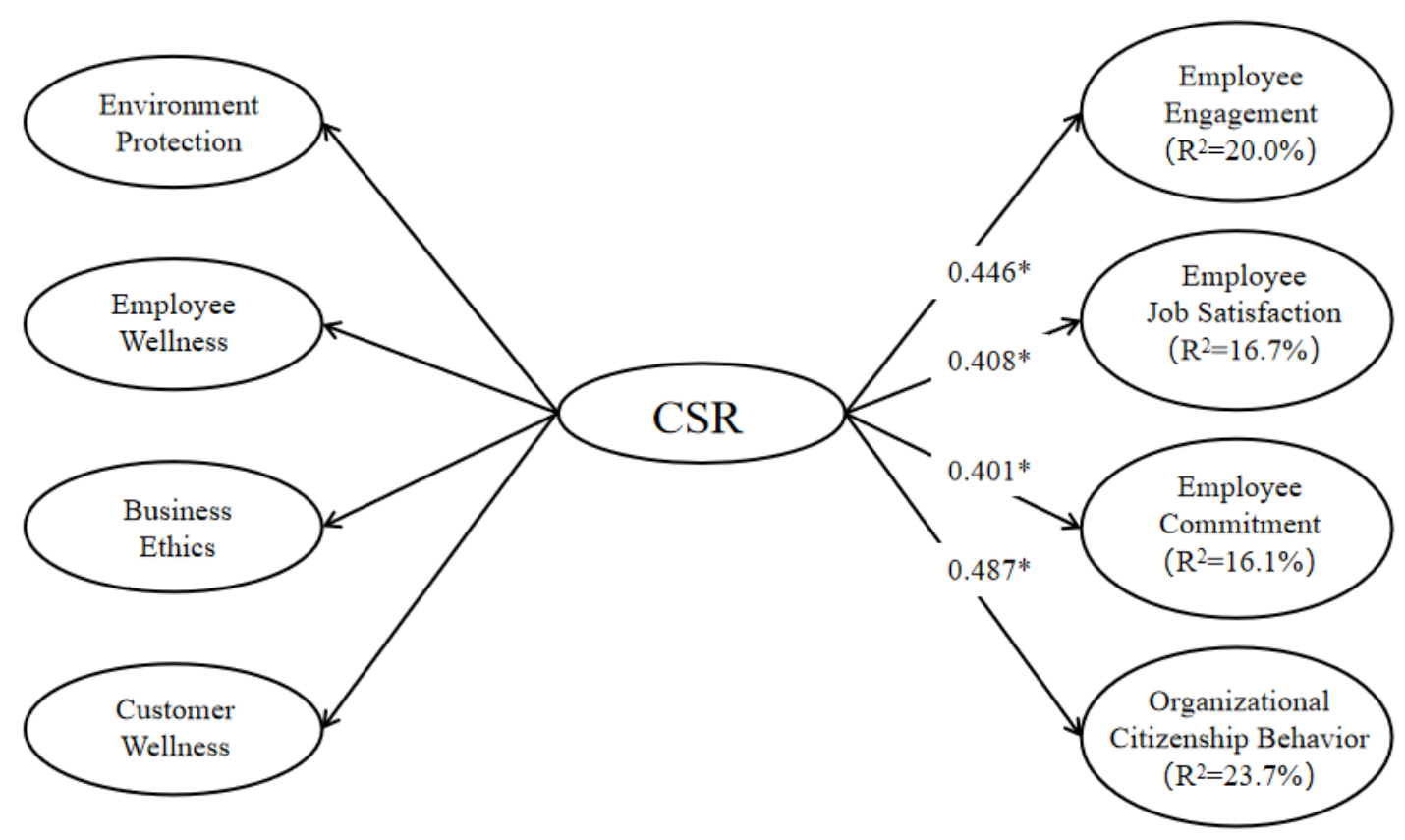

Note: ${ }^{*} p<0.01$

Figure. 3. Structural model 
Table 1. Summary of CSR definition and dimension.

\begin{tabular}{|c|c|c|c|c|}
\hline Authors (year) & Context & Perspective & Definition & Dimension \\
\hline $\begin{array}{l}\text { Levy \& Park } \\
(2011)\end{array}$ & $\begin{array}{l}\text { Lodging industry in } \\
\text { America }\end{array}$ & $\begin{array}{l}\text { General } \\
\text { manager }\end{array}$ & $\begin{array}{l}\text { CSR has often been cited as "the continuing commitment by business to } \\
\text { behave ethically and contribute to economic development while } \\
\text { improving the quality of life, of the workforce, and their families, as well } \\
\text { as of the local community and society at large" (World Business Council } \\
\text { for Sustainable Development, 1999) and considered "a concept whereby } \\
\text { companies integrate social and environmental concerns in their business } \\
\text { operations and in their interaction with their stakeholders on a voluntary } \\
\text { basis" (European Commission, 2001). }\end{array}$ & $\begin{array}{l}\text { Community relations, } \\
\text { Diversity issues, } \\
\text { Employee relations, } \\
\text { Environmental issues, } \\
\text { Product quality }\end{array}$ \\
\hline $\begin{array}{l}\text { Tsai, Tsang, \& } \\
\text { Cheng (2012) }\end{array}$ & $\begin{array}{l}\text { Hotel industry in } \\
\text { Hong Kong }\end{array}$ & Employee & $\begin{array}{l}\text { CSR is described as the continuous commitment by business through } \\
\text { behaving ethically in their trade and contribute to economic } \\
\text { development, at the same time improving the quality of life of the } \\
\text { workforce and their families as well as the local community and society } \\
\text { at large (World Business Council for Sustainable Development, 1999). }\end{array}$ & $\begin{array}{l}\text { State of affairs, } \\
\text { Internal and external } \\
\text { consumers, } \\
\text { Business ethics, } \\
\text { Community interest, } \\
\text { Novelty, } \\
\text { Financial }\end{array}$ \\
\hline $\begin{array}{l}\text { Kucukusta, Mak, } \\
\text { \& Chan (2013) }\end{array}$ & Hotel industry in $\mathrm{HK}$ & Tourist & $\begin{array}{l}\text { The essence of CSR is that a company should consider the interests of } \\
\text { different parties when making business decisions. }\end{array}$ & $\begin{array}{l}\text { Community, } \\
\text { Policy, } \\
\text { Mission \& Vision, } \\
\text { Workforce, } \\
\text { Environment }\end{array}$ \\
\hline $\begin{array}{l}\text { Martínez, Pérez, \& } \\
\text { Rodríguez } \\
\text { (2013) }\end{array}$ & $\begin{array}{l}\text { Hotel industry in } \\
\text { Spain }\end{array}$ & Customer & $\begin{array}{l}\text { The definition proposed by Panwar, Rinne, Hansen, and Juslin (2006), } \\
\text { who define this construct as a strategic and proactive way of doing } \\
\text { business in a specific context with a synergistic philosophy. }\end{array}$ & $\begin{array}{l}\text { Economic, } \\
\text { Social, } \\
\text { Environmental }\end{array}$ \\
\hline $\begin{array}{l}\text { Fu, Ye, \& Law } \\
(2014)\end{array}$ & $\begin{array}{l}\text { Hotel industry (mid- } \\
\text { and upscale brands) in } \\
\text { southern China }\end{array}$ & Employee & $\begin{array}{l}\text { Carroll (1979) proposes a more comprehensive definition of CSR by } \\
\text { suggesting that "the social responsibility of business encompasses the } \\
\text { economic, legal, ethical, and discretionary expectations that society has } \\
\text { of organizations at a given point in time". }\end{array}$ & $\begin{array}{l}\text { Economic, } \\
\text { Legal, } \\
\text { Philanthropic, } \\
\text { Ethical }\end{array}$ \\
\hline $\begin{array}{l}\text { Park \& Levy } \\
(2014)\end{array}$ & $\begin{array}{l}\text { Hospitality industry in } \\
\text { the U.S. }\end{array}$ & Frontline employee & $\begin{array}{l}\text { CSR commonly refers to the relationship between businesses and } \\
\text { society, which denotes firms' actions to balance financial performance, } \\
\text { impacts on society and the environment. }\end{array}$ & $\begin{array}{l}\text { Environment, } \\
\text { Community, } \\
\text { Employees, } \\
\text { Customers }\end{array}$ \\
\hline
\end{tabular}




\begin{tabular}{|c|c|c|c|c|}
\hline $\begin{array}{l}\text { Fatma, Rahman \& } \\
\text { Khan (2016) }\end{array}$ & $\begin{array}{l}\text { Tourism industry in } \\
\text { India }\end{array}$ & Consumer & $\begin{array}{l}\text { CSR is a firm's commitment to maximize long-term economic, social } \\
\text { and environmental well-being through business practices, policies and } \\
\text { resources (Du \& Vieira, 2012). }\end{array}$ & $\begin{array}{l}\text { Economic, } \\
\text { Social, } \\
\text { Environmental }\end{array}$ \\
\hline $\begin{array}{l}\text { Kim, Song \& Lee } \\
\text { (2016) }\end{array}$ & $\begin{array}{l}\text { Casino industry in } \\
\text { South Korea }\end{array}$ & Employee & $\begin{array}{l}\text { Carroll's (1991, 1998) definition with four CSR dimensions has been } \\
\text { commonly adapted: a company should (1) make goods or services for } \\
\text { consumers to yield a satisfactory profit in the process (economic } \\
\text { responsibility), (2) comply with laws and regulations stated by } \\
\text { governments in its operations (legal), (3) meet expectations of } \\
\text { stakeholders and protect them regardless if these activities are not } \\
\text { codified into law (ethical), and (4) meet stakeholders' expectations on the } \\
\text { company's engagement to enhance human welfare or good will } \\
\text { (philanthropic). }\end{array}$ & $\begin{array}{l}\text { Economic, } \\
\text { Legal, } \\
\text { Ethical, } \\
\text { Philanthropic }\end{array}$ \\
\hline $\begin{array}{l}\text { Ilkhanizadeh \& } \\
\text { Karatepe (2017) }\end{array}$ & $\begin{array}{l}\text { Airline industry in } \\
\text { Turkey }\end{array}$ & Flight attendant & $\begin{array}{l}\text { Corporate social responsibility (CSR), which refers to "context-specific } \\
\text { organizational actions and policies that take into account stakeholders' } \\
\text { expectations and the triple bottom line of economic, social, and } \\
\text { environmental performance" (Aguinis, 2011). }\end{array}$ & $\begin{array}{l}\text { Economic, } \\
\text { Legal, } \\
\text { Ethical, } \\
\text { Philanthropic }\end{array}$ \\
\hline Kim et al. (2017) & $\begin{array}{l}\text { Hotel industry in } \\
\text { South Korea }\end{array}$ & Frontline employee & $\begin{array}{l}\text { Carroll (1979) suggested a model of CSR which includes economic, } \\
\text { legal, ethical and discretionary [later referred to as philanthropic] } \\
\text { categories. }\end{array}$ & $\begin{array}{l}\text { Legal, } \\
\text { Ethical, } \\
\text { Philanthropic, } \\
\text { Economic }\end{array}$ \\
\hline $\begin{array}{l}\text { Su, Pan, \& Chen } \\
\text { (2017) }\end{array}$ & $\begin{array}{l}\text { Hospitality industry in } \\
\text { mid-south China }\end{array}$ & Tourist & $\begin{array}{l}\text { Firms tend to act on both economic and ethical obligations to their } \\
\text { stakeholders. They can reap enormous benefits when their stakeholders } \\
\text { perceive them as concerned citizens practicing business in a socially } \\
\text { responsible manner (Fu, Ye, \& Law, 2014; Tian, Wang, \& Yang, 2011). } \\
\text { CSR refers to "the commitment of businesses to behave ethically and to }\end{array}$ & $\begin{array}{l}\text { Environmental, } \\
\text { Social, } \\
\text { Economic, } \\
\text { Stakeholders }\end{array}$ \\
\hline $\begin{array}{l}\text { Youn, Lee, \& Lee } \\
\text { (2018) }\end{array}$ & $\begin{array}{l}\text { Casino industry in } \\
\text { South Korea }\end{array}$ & Employee & $\begin{array}{l}\text { contribute to sustainable economic development by working with all } \\
\text { relevant stakeholders to improve their lives in ways that are good for } \\
\text { business, the sustainable development agenda, and society at large” } \\
\text { (Kitzmueller \& Shimshack, 2012). }\end{array}$ & $\begin{array}{l}\text { Social stakeholders, } \\
\text { Non-social stakeholders }\end{array}$ \\
\hline
\end{tabular}


Table 2. Summary of international hotel groups' CSR projects

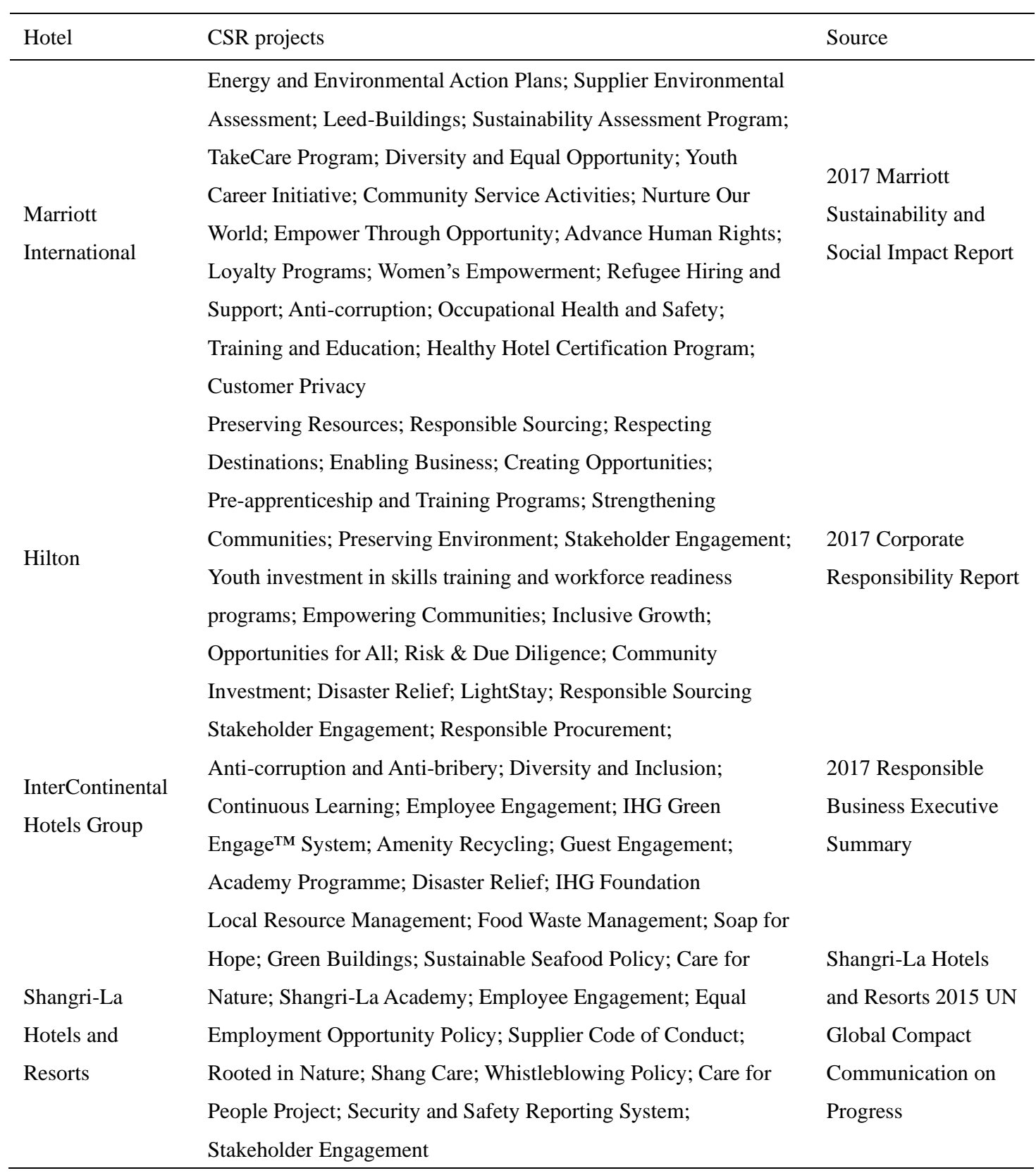


Table 3. Initial generation of CSR dimensions and items

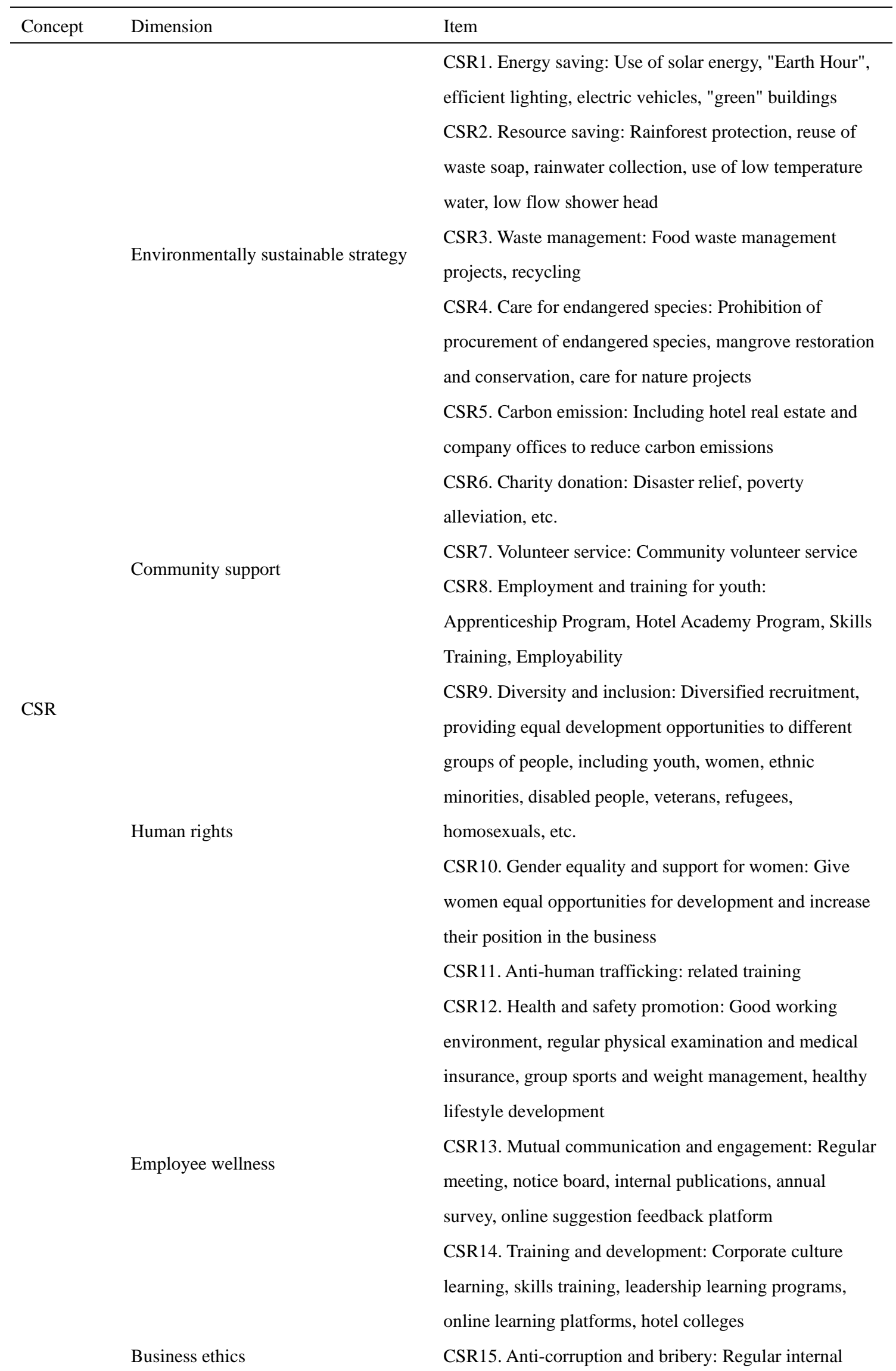


audits, and encourage reporting

CSR16. Responsible procurement and sourcing: Safe and reliable procurement of raw materials

CSR17. Safety and privacy: Effectively protect the personal and property safety of guests and protect

Customer wellness personal privacy

CSR18. Health and well-being: Formulating hygiene standards, ensuring food safety, and promoting healthy eating 
Table 4. Demographic profiles and work background information of respondents.

\begin{tabular}{|c|c|c|c|}
\hline \multicolumn{2}{|c|}{ Category } & Frequency & Percentage $(\%)$ \\
\hline \multirow{2}{*}{ Gender } & Male & 257 & 42.5 \\
\hline & Female & 348 & 57.5 \\
\hline \multirow{5}{*}{ Age } & $18-24$ & 181 & 29.9 \\
\hline & $25-35$ & 202 & 33.4 \\
\hline & $36-45$ & 108 & 17.9 \\
\hline & $46-60$ & 114 & 18.8 \\
\hline & $>60$ & 0 & 0 \\
\hline \multirow{4}{*}{ Education } & High school or below & 246 & 40.7 \\
\hline & 2-year college degree & 223 & 36.9 \\
\hline & Bachelor degree & 129 & 21.3 \\
\hline & Master degree or above & 7 & 1.2 \\
\hline \multirow{6}{*}{ Monthly Income } & $<3000 \mathrm{RMB}$ & 279 & 46.1 \\
\hline & 3000-4999 RMB & 202 & 33.4 \\
\hline & 5000-7999 RMB & 81 & 13.4 \\
\hline & 8000-9999 RMB & 14 & 2.3 \\
\hline & 10000-11999 RMB & 14 & 2.3 \\
\hline & $>12000 \mathrm{RMB}$ & 15 & 2.5 \\
\hline \multirow{4}{*}{ Working years in this hotel } & $\leqslant 1$ year & 195 & 32.2 \\
\hline & 1-3 (included) years & 166 & 27.4 \\
\hline & 3-5 (included) years & 96 & 15.9 \\
\hline & $>5$ years & 148 & 24.5 \\
\hline \multirow{5}{*}{ Working years in the hotel industry } & $\leqslant 1$ year & 113 & 18.7 \\
\hline & 1-3 (included) years & 152 & 25.1 \\
\hline & 3-5 (included) years & 121 & 20.0 \\
\hline & 5-10 (included) years & 121 & 20.0 \\
\hline & $>10$ years & 98 & 16.2 \\
\hline \multirow{4}{*}{ Job level } & Primary-level employee & 380 & 62.8 \\
\hline & Primary-level manager & 148 & 24.5 \\
\hline & Middle-level manager & 65 & 10.7 \\
\hline & High-level manager & 12 & 2.0 \\
\hline \multirow{9}{*}{ Department } & Food and beverage department & 253 & 41.8 \\
\hline & Housekeeping department & 177 & 29.3 \\
\hline & Engineering department & 36 & 6.0 \\
\hline & Human resources department & 42 & 6.9 \\
\hline & Finance department & 30 & 5.0 \\
\hline & Marketing department & 22 & 3.6 \\
\hline & Security department & 26 & 4.3 \\
\hline & Executive office & 10 & 1.7 \\
\hline & Other departments & 9 & 1.5 \\
\hline \multicolumn{2}{|c|}{ Total } & 605 & 100.0 \\
\hline
\end{tabular}


Table 5. Exploratory factor analysis results for initial measurement items (n=605).

\begin{tabular}{|c|c|c|c|c|}
\hline Dimension and Item description & $\mathrm{EP}$ & EW & $\mathrm{BE}$ & $\mathrm{CW}$ \\
\hline \multicolumn{5}{|l|}{ Environment protection (EP) } \\
\hline CSR 1. Energy saving & 0.763 & & & \\
\hline CSR 2. Resource saving & 0.794 & & & \\
\hline CSR 3. Waste management & 0.719 & & & \\
\hline \multicolumn{5}{|l|}{ Employee wellness (EW) } \\
\hline CSR 12. Wage security & & 0.716 & & \\
\hline CSR 13 . Health and safety promotion & & 0.815 & & \\
\hline CSR 14. Mutual communication and engagement & & 0.816 & & \\
\hline CSR 15. Training and development & & 0.755 & & \\
\hline \multicolumn{5}{|l|}{ Business ethics (BE) } \\
\hline CSR 16. Anti-corruption and bribery & & & 0.734 & \\
\hline CSR 17. Responsible procurement and sourcing & & & 0.726 & \\
\hline CSR 18. Fair competition and cooperation & & & 0.813 & \\
\hline \multicolumn{5}{|l|}{ Customer wellness (CW) } \\
\hline CSR 19. Safety and privacy & & & & 0.712 \\
\hline CSR 20. Health and well-being & & & & 0.744 \\
\hline CSR 21. Right to know & & & & 0.702 \\
\hline Cronbach's a & 0.796 & 0.799 & 0.834 & 0.868 \\
\hline$\%$ of variance & 41.739 & 9.559 & 5.421 & 3.691 \\
\hline Kaiser-Meyer-Olkin Measure of Sampling Adequacy. & \multicolumn{4}{|l|}{0.851} \\
\hline Bartlett's test of sphericity & \multicolumn{4}{|c|}{$831.693(\mathrm{p}<0.001)$} \\
\hline
\end{tabular}


Table 6. Demographic profiles and work background information of respondents.

\begin{tabular}{|c|c|c|c|}
\hline \multicolumn{2}{|c|}{ Category } & Frequency & Percentage $(\%)$ \\
\hline \multirow{2}{*}{ Gender } & Male & 433 & 42.3 \\
\hline & Female & 590 & 57.7 \\
\hline \multirow{5}{*}{ Age } & $18-24$ & 188 & 18.4 \\
\hline & $25-35$ & 384 & 37.5 \\
\hline & $36-45$ & 270 & 26.4 \\
\hline & $46-60$ & 176 & 17.2 \\
\hline & $>60$ & 5 & 0.5 \\
\hline \multirow{4}{*}{ Education } & High school or below & 480 & 46.9 \\
\hline & 2-year college degree & 422 & 41.3 \\
\hline & Bachelor degree & 118 & 11.5 \\
\hline & Master degree or above & 3 & 0.3 \\
\hline \multirow{6}{*}{ Monthly Income } & $<3000 \mathrm{RMB}$ & 473 & 46.2 \\
\hline & 3000-4999 RMB & 387 & $37 . .8$ \\
\hline & 5000-7999 RMB & 133 & 13.0 \\
\hline & 8000-9999 RMB & 22 & 2.2 \\
\hline & 10000-11999 RMB & 5 & 0.5 \\
\hline & $>12000 \mathrm{RMB}$ & 3 & 0.3 \\
\hline \multirow{4}{*}{ Working years in this hotel } & $\leqslant 1$ year & 222 & 21.7 \\
\hline & 1-3 (included) years & 396 & 38.7 \\
\hline & 3-5 (included) years & 196 & 19.2 \\
\hline & $>5$ years & 209 & 20.4 \\
\hline \multirow{5}{*}{ Working years in the hotel industry } & $\leqslant 1$ year & 132 & 12.9 \\
\hline & 1-3 (included) years & 318 & 31.1 \\
\hline & 3-5 (included) years & 209 & 20.4 \\
\hline & 5-10 (included) years & 235 & 23.0 \\
\hline & $>10$ years & 129 & 12.6 \\
\hline \multirow{4}{*}{ Job level } & Primary-level employee & 574 & 56.1 \\
\hline & Primary-level manager & 344 & 33.6 \\
\hline & Middle-level manager & 97 & 9.5 \\
\hline & High-level manager & 8 & 0.8 \\
\hline \multirow{9}{*}{ Department } & Food and beverage department & 345 & 33.7 \\
\hline & Housekeeping department & 331 & 32.4 \\
\hline & Engineering department & 99 & 9.7 \\
\hline & Human resources department & 38 & 3.7 \\
\hline & Finance department & 35 & 3.4 \\
\hline & Marketing department & 82 & 8.0 \\
\hline & Security department & 69 & 6.7 \\
\hline & Executive office & 7 & 0.7 \\
\hline & Other departments & 17 & 1.7 \\
\hline \multicolumn{2}{|c|}{ Total } & 1023 & 100.0 \\
\hline
\end{tabular}


Table 7. Convergent validity and reliability of the constructs

\begin{tabular}{|c|c|c|c|}
\hline Construct and items & Loadings & AVE & $\mathrm{CR}$ \\
\hline Environment protection & & 0.531 & 0.772 \\
\hline Energy saving & 0.835 & & \\
\hline Resource saving & 0.812 & & \\
\hline Waste management & 0.780 & & \\
\hline Employee wellness & & 0.591 & 0.794 \\
\hline Wage security & 0.716 & & \\
\hline Health and safety promotion & 0.723 & & \\
\hline Mutual communication and engagement & 0.779 & & \\
\hline Training and development & 0.763 & & \\
\hline Business ethics & & 0.510 & 0.757 \\
\hline Anti-corruption and bribery & 0.824 & & \\
\hline Responsible procurement and sourcing & 0.810 & & \\
\hline Fair competition and cooperation & 0.803 & & \\
\hline Customer wellness & & 0.546 & 0.782 \\
\hline Safety and privacy & 0.774 & & \\
\hline Health and well-being & 0.820 & & \\
\hline Right to know & 0.786 & & \\
\hline
\end{tabular}


Table 8. Discriminant validity

\begin{tabular}{lcccc}
\hline & BE & CW & EW & EP \\
\hline Business Ethnics & $\mathbf{0 . 7 1 4}$ & & & \\
Customer Wellness & 0.543 & $\mathbf{0 . 7 3 9}$ & & \\
Employee Wellness & 0.435 & 0.441 & $\mathbf{0 . 7 6 8}$ & $\mathbf{0 . 7 2 9}$ \\
Environment Protection & 0.517 & 0.482 & 0.465 & \\
\hline
\end{tabular}

Note: the square root of the average variance extracted (AVE) (in bold) and correlations between constructs (off-diagonal) 
Table 9. Weights of the first order constructs on the second-order constructs

\begin{tabular}{lllll}
\hline Second-order constructs & First-order constructs & Weight & t-value & VIF \\
\hline Corporate social responsibility & Environment protection & 0.315 & $15.089^{* * * *}$ & 1.677 \\
& Employee wellness & 0.371 & $17.536^{* * * *}$ & 1.753 \\
& Business ethics & 0.277 & $18.497^{* * * *}$ & 1.672 \\
& Customer wellness & 0.273 & $18.330^{* * * *}$ & 1.872 \\
\hline
\end{tabular}

Note: $* \mathrm{P}<0.05, * * \mathrm{P}<0.01, * * * \mathrm{P}<0.001$ 
Table 10. Structural estimates (Hypotheses testing) and blindfolding procedures

\begin{tabular}{lccccc}
\hline Hypotheses & $\begin{array}{c}\text { Standardized } \\
\text { Coefficient }\end{array}$ & t-value & Decision & $\mathrm{f}^{2}$ & $\mathrm{Q}^{2}$ \\
\hline $\mathrm{CSR} \rightarrow$ Employee engagement & 0.446 & $14.104^{* * *}$ & Supported & 0.34 & 0.14 \\
$\mathrm{CSR} \rightarrow$ Employee commitment & 0.401 & $12.188^{* * * *}$ & Supported & 0.33 & 0.15 \\
$\mathrm{CSR} \rightarrow$ Employee job satisfaction & 0.408 & $12.941^{* * *}$ & Supported & 0.25 & 0.06 \\
$\mathrm{CSR} \rightarrow$ Organizational citizenship behavior & 0.487 & $15.610^{* * *}$ & Supported & 0.24 & 0.09 \\
\hline
\end{tabular}

Note: $* \mathrm{P}<0.05, * * \mathrm{P}<0.01, * * * \mathrm{P}<0.001$ 
Appendix 1. Descriptive statistics and normality test results

\begin{tabular}{|c|c|c|c|c|c|c|c|c|}
\hline & \multirow{2}{*}{$\begin{array}{c}\text { Minimum } \\
\text { Statistic }\end{array}$} & \multirow{2}{*}{$\frac{\text { Maximum }}{\text { Statistic }}$} & \multirow{2}{*}{$\begin{array}{c}\text { Mean } \\
\text { Statistic }\end{array}$} & \multirow{2}{*}{$\frac{\text { Std. Deviation }}{\text { Statistic }}$} & \multicolumn{2}{|c|}{ skewness } & \multicolumn{2}{|c|}{ Kurtosis } \\
\hline & & & & & Statistic & Std. Error & Statistic & Std. Error \\
\hline CSR1 & 1 & 5 & 4.23 & 0.75 & -0.92 & 0.101 & 1.282 & 0.202 \\
\hline CSR2 & 1 & 5 & 4.24 & 0.72 & -0.895 & 0.102 & 1.543 & 0.203 \\
\hline CSR3 & 1 & 5 & 4.17 & 0.823 & -1.112 & 0.103 & 1.99 & 0.206 \\
\hline CSR4 & 1 & 5 & 4.18 & 0.822 & -0.8 & 0.104 & 0.466 & 0.208 \\
\hline CSR5 & 1 & 5 & 4.2 & 0.767 & -0.748 & 0.103 & 0.319 & 0.206 \\
\hline CSR6 & 1 & 5 & 4.25 & 0.78 & -1.058 & 0.108 & 1.594 & 0.215 \\
\hline CSR7 & 1 & 5 & 4.26 & 0.758 & -0.794 & 0.104 & 0.327 & 0.208 \\
\hline CSR8 & 1 & 5 & 4.1 & 0.84 & -0.917 & 0.107 & 1.104 & 0.214 \\
\hline CSR9 & 1 & 5 & 4.09 & 0.833 & -0.689 & 0.105 & 0.313 & 0.209 \\
\hline CSR10 & 1 & 5 & 4.17 & 0.777 & -0.987 & 0.104 & 1.8 & 0.207 \\
\hline CSR11 & 1 & 5 & 4.16 & 0.792 & -0.958 & 0.104 & 1.557 & 0.208 \\
\hline CSR12 & 1 & 5 & 4.43 & 0.761 & -1.445 & 0.1 & 1.491 & 0.2 \\
\hline CSR13 & 1 & 5 & 4.34 & 0.761 & -1.315 & 0.101 & 1.529 & 0.201 \\
\hline CSR14 & 1 & 5 & 4.16 & 0.797 & -0.893 & 0.1 & 1.034 & 0.2 \\
\hline CSR15 & 1 & 5 & 4.16 & 0.814 & -0.916 & 0.101 & 1.14 & 0.202 \\
\hline CSR16 & 1 & 5 & 3.96 & 0.823 & -0.302 & 0.105 & -0.568 & 0.21 \\
\hline CSR17 & 1 & 5 & 4.21 & 0.738 & -1.106 & 0.105 & 1.562 & 0.21 \\
\hline CSR18 & 1 & 5 & 4.12 & 0.783 & -0.867 & 0.104 & 1.33 & 0.207 \\
\hline CSR19 & 1 & 5 & 4.44 & 0.718 & -1.393 & 0.101 & 1.58 & 0.202 \\
\hline CSR20 & 1 & 5 & 4.35 & 0.767 & -1.39 & 0.101 & 0.875 & 0.201 \\
\hline CSR21 & 1 & 5 & 4.28 & 0.762 & -1.182 & 0.102 & 1.401 & 0.204 \\
\hline EE1 & 1 & 7 & 5.57 & 1.217 & -1.402 & 0.099 & 1.304 & 0.198 \\
\hline EE2 & 1 & 7 & 5.74 & 1.155 & -1.485 & 0.099 & 1.84 & 0.198 \\
\hline EE3 & 1 & 7 & 5.86 & 1.189 & -1.514 & 0.099 & 0.759 & 0.198 \\
\hline EE4 & 1 & 7 & 5.03 & 1.516 & -0.823 & 0.099 & 0.112 & 0.198 \\
\hline EE5 & 1 & 7 & 5.76 & 1.113 & -1.162 & 0.099 & 1.651 & 0.198 \\
\hline EE6 & 1 & 7 & 5.81 & 1.167 & -1.424 & 0.099 & 0.647 & 0.198 \\
\hline EE7 & 1 & 7 & 5.61 & 1.18 & -0.846 & 0.099 & 0.79 & 0.198 \\
\hline OCB1 & 1 & 7 & 5.72 & 1.071 & -1.48 & 0.099 & 0.678 & 0.198 \\
\hline OCB2 & 1 & 7 & 6.01 & 1.077 & -1.657 & 0.099 & 0.663 & 0.198 \\
\hline OCB3 & 1 & 7 & 6.25 & 0.888 & -1.798 & 0.099 & 1.289 & 0.198 \\
\hline OCB4 & 1 & 7 & 6.17 & 0.951 & -1.973 & 0.099 & 1.044 & 0.198 \\
\hline OCB5 & 1 & 7 & 5.7 & 1.036 & -0.918 & 0.099 & 1.589 & 0.198 \\
\hline OCB6 & 1 & 7 & 5.54 & 1.242 & -0.898 & 0.099 & 0.897 & 0.198 \\
\hline $\mathrm{EC} 1$ & 1 & 7 & 5.79 & 1.154 & -1.403 & 0.099 & 1.621 & 0.198 \\
\hline $\mathrm{EC} 2$ & 1 & 7 & 5.79 & 1.071 & -1.028 & 0.099 & 0.756 & 0.198 \\
\hline EC3 & 1 & 7 & 5.76 & 1.132 & -1.324 & 0.099 & 1.263 & 0.198 \\
\hline EC4 & 1 & 7 & 5.94 & 1.129 & -1.588 & 0.099 & 1.35 & 0.198 \\
\hline EJS1 & 1 & 7 & 5.98 & 1.022 & -1.305 & 0.099 & 0.7 & 0.198 \\
\hline EJS2 & 1 & 7 & 5.7 & 1.319 & -1.421 & 0.099 & 1.115 & 0.198 \\
\hline
\end{tabular}




\begin{tabular}{lllllllll} 
EJS3 & 1 & 7 & 5.69 & 1.238 & -1.474 & 0.099 & 1.535 & 0.198 \\
EJS4 & 1 & 7 & 4.1 & 1.923 & -0.175 & 0.099 & -1.141 & 0.198 \\
\hline
\end{tabular}

Note. CSR: corporate social responsibility; EE: employee engagement; OCB: organizational citizenship behavior; EC: employee commitment; EJS: employee job satisfaction 